\title{
Effective energy : a concept of energy utilization applied across species
}

\author{
BY G. C. EMMANS \\ Genetics and Behavioural Sciences Department, Scottish Agricultural College, Bush Estate, \\ Penicuik, Midlothian EH26 OQE
}

(Received 19 January 1993 - Revised 9 August 1993 - Accepted 27 October 1993)

\begin{abstract}
An energy system is described in which, in both single-stomached and ruminant animals, the heat increment of feeding is considered to be linearly related to five measurable quantities. For both kinds of animals three of the quantities, with their heat increments in parentheses, are urinary $\mathbf{N}\left(w_{u} ; \mathrm{kJ} / \mathrm{g}\right)$, faecal organic matter $\left(w_{d} ; k J / g\right)$ and positive protein retention $\left(w_{p} ; k J / g\right)$. In ruminants the other two, with their heat increments in parentheses, are $\mathrm{CH}_{4}$ energy $\left(\mathrm{w}_{\mathrm{m}} ; \mathrm{kJ} / \mathrm{kJ}\right)$ and positive lipid retention ( $\mathrm{w}_{1}$; $\mathrm{kJ} / \mathrm{g})$; in single-stomached animals they are positive lipid retention from feed lipid $\left(w_{\|} ; \mathrm{kJ} / \mathrm{g}\right)$, and positive lipid retention not from feed lipid $\left(w_{1} ; \mathbf{k J} / \mathbf{g}\right)$. Data from suitable experiments on steers, pigs and chickens were used to test the system and to estimate $w_{u} 29 \cdot 2, w_{d} 3.80, w_{p} 36 \cdot 5, w_{m} 0 \cdot 616, w_{1} 16 \cdot 4$ and $w_{11}$ 4.4. The values for $w_{u}, w_{d}, w_{m}$ and $\left(w_{1}-w_{11}\right)$ allow an energy scale, called effective energy, to be defined for both single-stomached animals and ruminants. On this energy scale the values of $w_{p}$ and $w_{1}$, together with the heats of combustion of protein and lipid of 23.8 and $39.6 \mathrm{~kJ} / \mathrm{g}$ respectively, allow the energy requirement to be expressed as $(\mathrm{MH}+50 \mathrm{PR}+56 \mathrm{LR})$ for both kinds of animal, where PR and LR are the rates of positive protein and lipid retention $(\mathrm{g} / \mathrm{d})$, and $\mathrm{MH}$ is the maintenance heat production (kJ/d) which can be estimated as 0.96 of the fasting heat production. The effective energy (EE) yielded to a ruminant animal by a feed ingredient can be estimated as $\mathrm{EE}(\mathrm{MJ} / \mathrm{kg}$ organic matter) $=1 \cdot 15 \mathrm{ME}-3.84-4.67 \mathrm{DCP}$, where $\mathrm{ME}$ is the metabolizable energy value $(\mathrm{MJ} / \mathrm{kg}$ organic matter) and DCP is the digested crude protein content $(\mathrm{kg} / \mathrm{kg}$ organic matter) with both measured at maintenance. Alternatively, EE can be estimated as EE $(\mathrm{MJ} / \mathrm{kg})=\mathrm{GE}(\mathrm{d}-0.228)-4.67 \mathrm{DCP}$, where GE is the gross energy $(\mathrm{MJ} / \mathrm{kg})$ and $\mathrm{d}$ is the energy digestibility $(\mathrm{MJ} / \mathrm{MJ})$ also measured at maintenance. The EE yielded to a single-stomached animal can be estimated as $\mathrm{EE}(\mathrm{kJ} / \mathrm{g})=1 \cdot 17 \mathrm{ME}-4 \cdot 2 \mathrm{CP}-2.44$, where $\mathrm{ME}(\mathrm{kJ} / \mathrm{g})$ is measured at, or corrected to, zero $\mathrm{N}$-retention and $\mathrm{CP}(\mathrm{g} / \mathrm{g})$ is the crude protein $(\mathrm{N} \times 6 \cdot 25)$ content of the feed ingredient. The system is simpler for ruminants, and more accurate for both kinds of animal, than those now in use. As effective energy values can be tabulated for ingredients, and are additive to the extent that ME values are additive, they can be used to formulate diets using linear programming.
\end{abstract}

Effective energy: Metabolizable energy: Ruminants: Single-stomached animals

'The feed of an animal is, as far as we know, the sole source of the energy whose transformations constitute the essential phenomena of physical life. This energy is contained in the feed as chemical energy, and the maximum quantity which any substance can furnish for the vital activities by its oxidation in the body is measured by its heat of combustion. (Some) of the chemical energy of the feed escapes unutilised. These losses are of two general classes. First, a portion... (leaves) the body as chemical energy in the visible excreta and in the combustible gases.... Second, ... a portion of the chemical energy of the feed ... results merely in a superfluous heat production.' In these words Armsby \& Fries (1915) set out two problems. The first is to be able to predict the metabolizable energy (ME; defined, by 
Armsby (1903), as the heat of combustion of the diet minus the combined heats of combustion of the excreta produced from it) which will be yielded to a given animal by a given diet. The second is to be able to predict the increase in heat production that will result from feeding a given animal one diet rather than another. The first problem is now seen as having been solved, in that ME values for different feed ingredients exist in feed tables for both ruminants and single-stomached animals. The second problem, the prediction of the heat increment of feeding, is the subject of the present paper.

Armsby \& Fries (1915) came to see the heat increment resulting from the feeding of an extra $1 \mathrm{~kg}$ of a given feed material as a characteristic which was independent of the level of feeding. On this view, heat increment (HI) values can be tabulated in the same way as ME values for different feed ingredients. Armsby \& Fries (1915) defined the net energy (NE) value as $\mathrm{NE}=\mathrm{ME}-\mathrm{HI}$ so that, on this view, NE values can also be tabulated. The resulting 'Armsby net energy system' is, thus, a very simple one but, unfortunately, it rests on a proposition that is false.

Forbes et al. $(1928,1930)$ gave steers different amounts of the same feed and found that 'the quantitive relationship of the heat production to the food consumption ... is such as to be expressed not by a straight line ... the heat increment value of the food, must differ with the plane of nutrition'. Given this finding, which has been confirmed many times since, it is not possible to tabulate HI, and hence NE, values for feed ingredients.

In the Armsby \& Fries (1915) system the fasting heat production (FHP) and the positive energy retention (ER) are added together to form a single variable. The next step in complexity is to distinguish between the two. Blaxter \& Wainman (1961), for example, related ER to feed intake by two straight lines, of different slope, which intersected at zero ER. This is more or less equivalent to saying that the HI of feeding, for a given food, has one value below maintenance (defined as a zero rate of ER), and another above maintenance. In this system, where positive energy retention is considered as a single variable, it would, in principle, be possible to tabulate separate NE values for maintenance and for positive ER for different feed ingredients.

Kielanowski (1965), considering pigs in particular, pointed out the now obvious fact that it was sensible to add ER as protein and lipid together only if their energetic efficiencies were the same. If this were not the case, or if it could not reasonably be assumed a priori to be the case, then positive ER could not be considered as a single variable. A distinction should then be made between positive retentions of protein and lipid. On this view there are three components of animal performance to be considered: maintenance (defined now as zero rates of retention of both protein and lipid), positive protein retention and positive lipid retention. In principle at least, separate NE values for maintenance, protein retention and lipid retention could be tabulated for different feed ingredients. If the ratios of these values, across ingredients, were to be constant, then a single value for each ingredient would suffice.

The system of Kellner $(1912,1915)$ assigned a single energy value to a feed ingredient, expressed as a weight of starch. In this system the requirements of the animal were expressed as quantities of starch equivalent for maintenance and ER; no distinction was made between energy retained as protein and lipid. This system, by expressing maintenance requirements in terms of an equivalent $E R$, overcomes the problem of the variable $\mathrm{HI}$ which exists in Armsby's system and still allows an energy value to be assigned to an ingredient. Its failure to distinguish between energy retained as protein and lipid is a disadvantage if the two energetic efficiencies are not the same.

Blaxter \& Boyne (1978) rejected the model of Blaxter \& Wainman (1961) which distinguished only between feeding below and above maintenance, and reverted to the exponential model of Blaxter \& Graham (1955), which had been abandoned by Blaxter \& 
Wainman (1961) and by Graham (1969). The analysis of Blaxter \& Boyne (1978), and the model that underlies it, is important as it is the basis of the official UK energy system for ruminants of the Agricultural Research Council (1980).

Blaxter \& Boyne (1978) made ER, with no distinction drawn between protein and lipid, an exponential function of energy intake, with both scaled by the fasting metabolism. The equation was $R=(B(1-\exp (-p I))-1)$ where $R$ is the scaled energy retention and $I$ the scaled energy intake; $B$ and $p$ are the parameters of the equation. Two alternative parameters are $k_{m}$ and $k_{f}$ which are defined such that $R=0$ when $I=1 / k_{m}$ and $R=k_{f}$ when $R=2 / k_{m}$. The parameter pairs are related to each other by the equations: $B=k_{m} /\left(k_{m}-k_{f}\right)$ and $p=k_{m} \cdot \log \left(k_{m} / k_{f}\right)$. The data from many experiments were used to estimate the values of the parameters of the model and, hence, to estimate $k_{m}$ and $k_{f}$ for different foods. Within a feed class, the values of the two efficiencies, $k_{m}$ and $k_{f}$, were treated as linear functions of $q$, the proportion of the gross energy (GE) that was metabolizable at the maintenance level of feeding. There were large differences between food classes in the relationships.

More recently Blaxter (1989), using the same data set, has expressed the values of $k_{m}$ and $k_{f+p}$, the efficiency of ER, as linear functions of $(1 / q)$ and $(P / q)$, where $P$ is the crude protein $(N \times 6.25)$ content of the feed; no mention is made of any difference between food classes.

The approach adopted in the present paper is to attempt to account for $\mathrm{HI}$ of feeding in a general way. The first problem is to account for HI, compared with the fast, of feeding a diet which results in positive retentions by the animal of neither protein nor lipid. Given a solution to this problem, the second is to account for the extra heat produced when these retentions are positive. As far as is possible no distinction is made between singlestomached animals and ruminants; only maintenance and growth, as positive retentions of protein and lipid, are considered.

\section{THE QUANTITIES IN THE SYSTEM}

\section{Metabolizable energy}

The potential energy supplied to the animal by its diet is the heat of combustion of that diet. Since it is only the organic matter which yields energy on combustion the potential energy supplied is the rate of intake of organic matter multiplied by its heat of combustion. Of this potential energy some may be lost as organic matter in the faeces, the urine and the combustible gases. A useful quantity is the energy of the diet which is not lost in any one of these three ways; this quantity was named ME by Armsby (1903) and, by definition, is given by:

$$
\mathrm{ME}(\mathrm{kJ} / \mathrm{d})=\mathrm{GE}-(\mathrm{FE}+\mathrm{UE}+\mathrm{MTHE})
$$

where ME here is the rate of supply of metabolizable energy, and FE, UE and MTHE the rates of loss of energy in the faeces, the urine and the combustible gases, considered here as $\mathrm{CH}_{4}$. An important problem is that of knowing, or being able to predict from other information, the ME that will be yielded to an animal by a given diet. This problem, for the purposes of the present paper, is assumed to have been solved.

The $\mathrm{ME}$ in equation 1 has been termed the classical $\mathrm{ME}$, or $\mathrm{ME}_{\mathrm{c}}$. For some purposes it is useful to correct it to the value which would have been expected to have been observed had the rate of $\mathrm{N}$ retention been zero. This quantity, the $\mathrm{N}$-corrected $\mathrm{ME}$ or catabolizable energy, $\mathrm{ME}_{n}$, is estimated as:

$$
\mathrm{ME}_{\mathrm{n}}(\mathrm{kJ} / \mathrm{d})=\mathrm{ME}_{\mathrm{c}}-\mathrm{a}(6 \cdot 25 \mathrm{NR}),
$$


where NR is $N$ retention $(\mathrm{g} / \mathrm{d})$. The value of ' $\mathrm{a}$ ' is assumed to be constant and to be close to $5.63 \mathrm{~kJ} / \mathrm{g}$. Where a necessary condition of maintenance is that the rate of protein retention is zero then $\mathrm{ME}_{\mathrm{n}}$ is the $\mathrm{ME}$ measured at maintenance.

\section{Heat production and the heat increment of feeding}

From the principle of the conservation of energy the ME yielded to an animal by its diet will either be retained in the animal or lost as heat. In other than the short run all the energy retained by the animal can be taken to be in the form of the potential energy of either protein or lipid, with the small amount of carbohydrate ignored. It follows that:

$$
\mathrm{ME}_{\mathrm{c}}(\mathrm{kJ} / \mathrm{d})=\mathrm{h}_{p} . \mathrm{PR}+\mathrm{h}_{l} . \mathrm{LR}+\mathrm{H},
$$

where $\mathrm{ME}_{\mathrm{c}}$ is the classical ME intake, $\mathrm{H}$ is the rate of heat production (and loss), PR and LR are the rates of retention of protein and lipid $(\mathrm{g} / \mathrm{d})$ and $h_{p}$ and $h_{l}$ are their heats of combustion $(\mathrm{kJ} / \mathrm{g})$. The values of $h_{p}$ and $h_{l}$ are assumed here to be 23.8 and $39.6 \mathrm{~kJ} / \mathrm{g}$ respectively; other estimates differ little from these. Where the ME is corrected to zero $\mathrm{N}$ retention the energy retention must also be corrected to give the equation:

$$
\mathrm{ME}_{\mathrm{n}}(\mathrm{kJ} / \mathrm{d})=\left(\mathrm{h}_{p}-\mathrm{a}\right) \cdot \mathrm{PR}+\mathrm{h}_{l} \cdot \mathrm{LR}+\mathrm{H} .
$$

Given the performance of the animal in a given state as values of PR and LR, the problem of predicting its $\mathrm{ME}$ requirement is thus that of predicting its rate of heat production. The components of $\mathrm{H}$ are described in the following sections.

\section{Fasting}

Armsby (1903) saw it as useful to consider $\mathrm{H}$ as having two components. The first, FHP, was the rate at which the animal would produce heat when given no feed and the second, HIF, was the increment in heat production resulting from feeding. FHP depends only on the animal; it can be seen as some function only of the kind of animal and its current state, providing that the environment is thermally neutral and the activity level of the animal is set at, or adjusted to, some constant level.

The heat produced by a fasting animal comes only from the catabolism of the protein and lipid of the body, once the small stock of carbohydrate has been exhausted. The heat produced by the catabolism of lipid is its heat of combustion. Protein catabolism leads to some energy appearing in the urine as N-containing compounds, so that the heat production of protein catabolism is less than its heat of combustion. The FHP is given by:

$$
\mathrm{FHP}(\mathrm{kJ} / \mathrm{d})=\left(\mathrm{h}_{p}-\mathrm{a}\right) \cdot \mathrm{PR}+\mathrm{h}_{l} . \mathrm{LR},
$$

where $P R$ and $L R(g / d)$ are the rates of loss during the fast considered as positive quantities.

Some part of FHP results from the synthesis and excretion of the $\mathrm{N}$-containing compounds in the urine. It is assumed that this 'heat of excretion' $(\mathrm{HEX} ; \mathrm{kJ} / \mathrm{d})$ is at the rate of $\mathrm{w}_{\mathrm{u}}(\mathrm{kJ} / \mathrm{gN})$ in the urine. FHP other than HEX is the maintenance heat production $(\mathrm{MH}) . \mathrm{MH}$ is the rate at which the animal would have produced heat when fasted had it been catabolizing only lipid. The relationships are:

$$
\begin{gathered}
\operatorname{HEX}(\mathrm{kJ} / \mathrm{d})=\mathrm{w}_{\mathrm{u}} \cdot \text { FUN, } \\
\mathrm{MH}(\mathrm{kJ} / \mathrm{d})=\text { FHP }- \text { HEX, }
\end{gathered}
$$

where FUN $(\mathrm{g} / \mathrm{d})$ is the rate of excretion of $\mathrm{N}$ during the fast. With $\mathrm{MH}$ taken as the base, rather than FHP, the fasting heat production includes a HI due to the fasting excretion. 


\section{Maintenance}

The animal is fed on a diet such that its rates of retention of both protein and lipid are zero; such a diet is defined here as a maintenance diet. The animal fed at maintenance will be eating food and, in the normal case, producing heat $(\mathrm{HM} ; \mathrm{kJ} / \mathrm{d})$ at a rate which is greater than $\mathrm{MH}$. The $\mathrm{HI}$ of the maintenance diet, relative to $\mathrm{MH}(\mathrm{HIM} ; \mathrm{kJ} / \mathrm{d})$ is given by:

$$
\operatorname{HIM}(\mathrm{kJ} / \mathrm{d})=\mathrm{HM}-\mathrm{MH} \text {. }
$$

The maintenance diet of organic matter (OMM; g/d) will lead to the excretion of $0 \cdot 16 \times \mathrm{DCP}=\mathrm{UN}(\mathrm{gN}$ in the urine $/ \mathrm{d}$ ) where DCP is the intake of digestible crude protein, as, by definition, no protein is retained. It will also lead to the production of methane (MTHE; $\mathrm{kJ} / \mathrm{d}$ ). It is assumed that $\mathrm{HI}$ over $\mathrm{MH}$, due to the animal eating its maintenance diet, is related to just three activities: its consumption of organic matter, its excretion of $\mathrm{N}$ in the urine, and its production of $\mathrm{CH}_{4}$. It is further assumed that the rates of heat production associated with these activities are linearly related to the quantities OMM, UN and MTHE. Thus, the HI, relative to $\mathrm{MH}$, due to the animal eating its maintenance diet is given by:

$$
\operatorname{HIM}(\mathrm{kJ} / \mathrm{d})=\mathrm{k} \cdot \mathrm{OMM}+\mathrm{w}_{\mathrm{u}} \cdot \mathrm{UN}+\mathrm{w}_{\mathrm{m}} \cdot \mathrm{MTHE},
$$

where $w_{m}$ is the heat associated with the production of $\mathrm{CH}_{4}(\mathrm{~kJ} / \mathrm{kJ})$. The value of $\mathrm{k}$ is assumed to differ between feeds with different values for the digestibility of their organic matter $(\mathrm{D} ; \mathrm{g} / \mathrm{g})$. For feeds with $\mathrm{D}$ values of 1 and 0 the value of $\mathrm{k}$ is assumed to be 0 and $\mathrm{w}_{\mathrm{cl}}(\mathrm{kJ} / \mathrm{g})$ respectively, and, for feeds between these extremes, to vary linearly with $\mathrm{D}$. It follows that $\mathrm{k}=\mathrm{w}_{\mathrm{d}} \cdot(1-\mathrm{D})$. The $\mathrm{kOMM}$ term becomes $\mathrm{w}_{\mathrm{d}} \cdot(1-\mathrm{D})$.OMM but, since (1-D). OMM is the faecal organic matter produced from the diet (FOM; g/d) then k.OMM can be substituted by $\mathrm{W}_{\text {id }}$. FOM. The equation for HIM becomes:

$$
\operatorname{HIM}(\mathrm{kJ} / \mathrm{d})=\mathrm{w}_{\mathrm{d}} \cdot \mathrm{FOM}+\mathrm{w}_{\mathrm{u}} \cdot \mathrm{UN}+\mathrm{w}_{\mathrm{m}} \cdot \text { MTHE. }
$$

The HI of different maintenance diets will increase as the digestible protein content and the yield of $\mathrm{CH}_{4}$ increase, and as $\mathrm{D}$ decreases. The amount of $\mathrm{ME}$ needed for maintenance $(\mathrm{MEM})$ is given by:

$$
\operatorname{MEM}(\mathrm{kJ} / \mathrm{d})=\mathrm{MH}+\mathrm{HIM}
$$

\section{Growth and fattening}

A diet which leads to positive retentions of protein and lipid, at the rates PR and $L R(g / d)$ will be associated with the production of $\mathrm{FOM}, \mathrm{UN}$ and $\mathrm{CH}_{4}$. A portion of $\mathrm{HI}$, relative to $\mathrm{MH}$, caused by the diet will be associated with the rates at which these latter three products are produced. But, in addition, it is assumed that there are two, and only two, additional $\mathrm{HI}$ that are associated with the positive retentions of protein and lipid. These HI are assumed to be directly proportional to PR and LR, with the constants of proportionality being $w_{p}$ and $w_{1}(\mathrm{~kJ} / \mathrm{g})$ respectively. Thus, for a diet leading to positive retentions of both protein and lipid, HIF relative to $\mathrm{MH}$ is given by:

$$
\operatorname{HIF}(\mathrm{kJ} / \mathrm{d})=\mathrm{w}_{\mathrm{d}} \cdot \mathrm{FOM}+\mathrm{w}_{\mathrm{u}} \cdot \mathrm{UN}+\mathrm{w}_{\mathrm{m}} \cdot \mathrm{MTHE}+\mathrm{w}_{\mathrm{p}} \cdot \mathrm{PR}+\mathrm{w}_{\mathrm{l}} \cdot \mathrm{LR} .
$$

The ME needed by the animal is given by:

$$
\mathrm{ME}(\mathrm{kJ} / \mathrm{d})=\mathrm{ER}+\mathrm{MH}+\mathrm{HIF} \text {. }
$$

As ER is the consequence of the performance of the animal, as rates of protein and lipid retention, and as MH depends only on the kind of animal and its state, it follows that the estimation of the ME needed by a given animal in a given state to attain some particular 


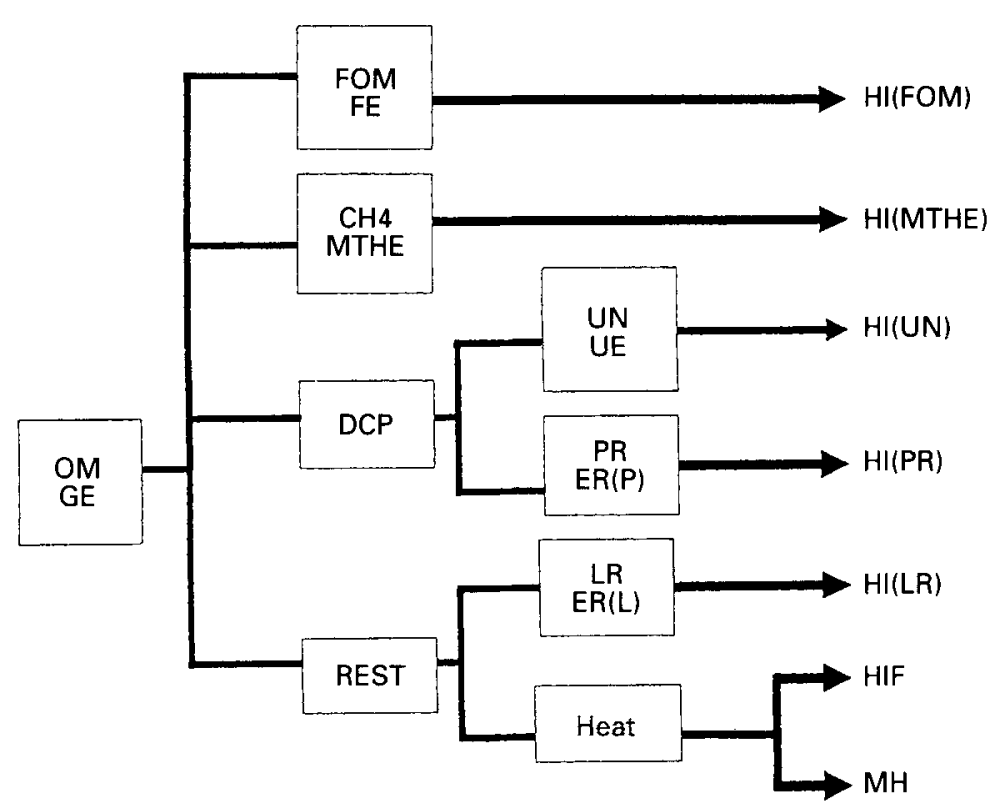

Fig. 1. Scheme for predicting the heat increment of feeding. The material components $(\mathrm{g} / \mathrm{d})$ are: OM, organic matter eaten; FOM, organic matter in faeces; DCP, apparently digested crude protein (nitrogen $\times 6.25$ ); REST, remaining organic matter; UN, urinary $N$; PR, positive protein retention; LR, positive lipid retention. The energy components (kJ/d) are: GE, gross energy eaten; FE, faecal energy; $\mathrm{MTHE}, \mathrm{CH}_{4}$ energy; UE, urinary energy; $\mathrm{ER}(\mathbf{P})$, energy retained as protein; $\mathrm{ER}(\mathrm{L})$, the energy retained as lipid. The heat components $(\mathrm{kJ} / \mathrm{d})$ are: $\mathrm{MH}$, maintenance heat; HIF, heat increment of feeding which has the components due to the separate heat increments of FOM, MTHE, UN, PR and LR as shown.

level of performance depends only on the estimation of HIF. Given the assumptions made previously, HIF can be estimated from the quantities FOM, UN, MTHE, PR and LR providing that the assumptions made are correct and that the values of the five constants $\mathrm{w}_{\mathrm{d}}, \mathrm{w}_{\mathrm{u}}, \mathrm{w}_{\mathrm{m}}, \mathrm{w}_{\mathrm{p}}$ and $\mathrm{w}_{\mathrm{l}}$ are known. The scheme to predict HIF is shown in Fig. 1.

\section{ESTIMATION OF CONSTANTS}

\section{Ruminants}

In principle it would be possible to measure $\mathrm{MH}$ for a given animal and then to give it a series of diets so that the quantities of FOM, UN, MTHE, PR and LR varied in an uncorrelated way. From such data the proposed system could be tested and, given its survival, the values of the five constants estimated. As no such experiment exists in the literature a more indirect approach was needed.

The literature was searched for suitable experiments on cattle in calorimeters where all the information needed was presented for individual animals. The experiments, all on castrated males, were of three kinds. In the first the same feed was given at two rates. In the second the same basal diet was given in two periods with an addition of another feed in one of the periods. In the third the two diets given differed in neither of these two systematic ways. In all cases the two treatments were on the same animal with, in most cases, two or more replicate animals. In one case the FOM outputs were not given; in this case they were estimated as $(\mathrm{FE} / 22.5 \mathrm{~g} / \mathrm{d})$ where $\mathrm{FE}$ is the faecal energy $(\mathrm{kJ} / \mathrm{d})$. (The estimate of the heat of combustion of FOM of $22.5 \mathrm{~kJ} / \mathrm{g}$ was based on data from several 
Table 1. The daily increments in heat $(H)$ and other quantities in fifteen calorimeter experiments on cattle*

\begin{tabular}{|c|c|c|c|c|c|c|}
\hline Expt no. & UN (g) & MTHE (kJ) & FOM $(g)$ & PR (g) & LR (g) & $\mathbf{H}(\mathrm{kJ})$ \\
\hline 1 & $-13 \cdot 1$ & 3738 & -101 & $22 \cdot 8$ & $-17 \cdot 8$ & 2056 \\
\hline 2 & $5 \cdot 3$ & 2219 & 328 & $27 \cdot 3$ & $44 \cdot 5$ & 4525 \\
\hline 3 & 36.7 & 1182 & 1261 & $5 \cdot 5$ & $-24 \cdot 1$ & 6528 \\
\hline 4 & $-22 \cdot 2$ & 1750 & 235 & $39 \cdot 5$ & $269 \cdot 8$ & 7212 \\
\hline 5 & $9 \cdot 1$ & 1191 & 870 & 25.9 & $130 \cdot 4$ & 7374 \\
\hline 6 & $169 \cdot 0$ & -400 & 52 & $38 \cdot 8$ & $65 \cdot 1$ & 7407 \\
\hline 7 & $28 \cdot 8$ & 2260 & 725 & $4 \cdot 4$ & 144.4 & 7480 \\
\hline 8 & $45 \cdot 9$ & 3479 & 1531 & 169 & $-45 \cdot 2$ & 9079 \\
\hline 9 & $-13 \cdot 2$ & 2346 & 1076 & $49 \cdot 5$ & $126 \cdot 6$ & 9146 \\
\hline 10 & $-4 \cdot 1$ & 1541 & 425 & $17 \cdot 4$ & 411.9 & 9847 \\
\hline 11 & $176 \cdot 5$ & 480 & 1 & $79 \cdot 7$ & 106.6 & 10119 \\
\hline 12 & 18.6 & 3254 & 545 & $131 \cdot 0$ & $208 \cdot 6$ & 12779 \\
\hline 13 & $12 \cdot 3$ & 4120 & 586 & $64 \cdot 4$ & $503 \cdot 2$ & 15844 \\
\hline 14 & $54 \cdot 3$ & 3640 & 1151 & $110 \cdot 9$ & $673 \cdot 6$ & 23190 \\
\hline 15 & $32 \cdot 4$ & 10490 & 1881 & 115.4 & $535 \cdot 3$ & 27543 \\
\hline
\end{tabular}

UN, urinary $\mathrm{N} ; \mathrm{MTHE}, \mathrm{CH}_{4}$ energy; FOM, faecal organic matter; PR, positive protein retention; LR, positive lipid retention.

* For details of published studies used, see Table 2.

Table 2. Brief description of the experiments providing the data given in Table 1

\begin{tabular}{|c|c|c|c|c|}
\hline Expt no. & Type* & Diet 1 & Diet 2 & Reference \\
\hline 1 & $\mathrm{C}$ & Basal +oil & Basal + starch & Kellner \& Kohler (1900) \\
\hline 2 & A & Mixed; $0.5 \mathrm{M}$ & Mixed; $1.0 \mathrm{M}$ & Forbes et al. $(1928,1930)$ \\
\hline 3 & $\mathrm{C}$ & Mixed; $1.0 \mathrm{M}$ & Hay; $1.0 \mathrm{M}$ & Forbes et al. $(1928,1930)$ \\
\hline 4 & $\mathbf{B}$ & Basal & Basal + starch & Kellner \& Kohler (1900) \\
\hline 5 & $\mathrm{~B}$ & Basal & Basal + cocoa hulls & Fingerling (1944) \\
\hline 6 & $\mathrm{C}$ & Basal + various & Basal + gluten & Kellner \& Kohler (1900) \\
\hline 7 & $\mathrm{~A}$ & Hay & Hay & Armsby \& Fries (1918) \\
\hline 8 & $\mathrm{C}$ & Maize; $1.0 \mathrm{M}$ & Hay; $1.0 \mathrm{M}$ & Forbes et al. $(1931 b)$ \\
\hline 9 & B & Basal & Basal + straw & Fingerling (1936) \\
\hline 10 & $\mathrm{~B}$ & Basal & Basal + potatoes & Fingerling (1933a) \\
\hline 11 & $\mathrm{C}$ & Basal + starch & Basal + gluten & Kellner \& Kohler (1900) \\
\hline 12 & A & Mixed;10 M & Mixed; high & Blaxter et al. (1966) \\
\hline 13 & $\mathrm{~B}$ & Basal & Basal + barley & Nehring et al. (1961) \\
\hline 14 & A & Mixed; low & Mixed; high & Armsby \& Fries (1917) \\
\hline 15 & $\mathrm{~A}$ & Fasting & Mixed; high & Forbes et al $(1928,1930)$ \\
\hline
\end{tabular}

$\mathbf{M}$, feeding at maintenance.

* The types of experiment are: A, the same feed at two levels; B, an addition to the same basal diet and C, others.

experiments where both quantities were reported; the variation in this value between diets was small.) Where the animals differed in weight between the two periods the $\mathrm{MH}$ was estimated to change by $60 \mathrm{~kJ} / \mathrm{kg}$ difference in estimated empty-body weight.

The differences in the quantities between the diet pairs are shown for the fifteen experiments in Table 1. The experiments are briefly described in Table 2 . The regression of $\mathrm{HI} v$. the increments in the five quantities was performed. The combination of experiments 
Table 3. Correlation coefficients for the independent variables obtained in fifteen calorimeter experiments on cattle $\uparrow$

\begin{tabular}{lrccc}
\hline \hline Variable & UN & MTHE & FOM & PR \\
\hline MTHE & -0.307 & - & - & - \\
FOM & -0.205 & $0.608^{*}$ & - & - \\
PR & 0.185 & $0.504^{*}$ & 0.187 & $-\overline{-}$ \\
LR & -0.132 & $0.505^{*}$ & 0.272 & $0.609^{*}$ \\
\hline
\end{tabular}

UN, urinary N; MTHE, $\mathrm{CH}_{4}$ energy; FOM, faecal organic matter; PR, positive protein retention; LR, positive lipid retention.

$* P<0.05$.

$\dagger$ For individual values, see Table 1 and for details of published studies, see Table 2.

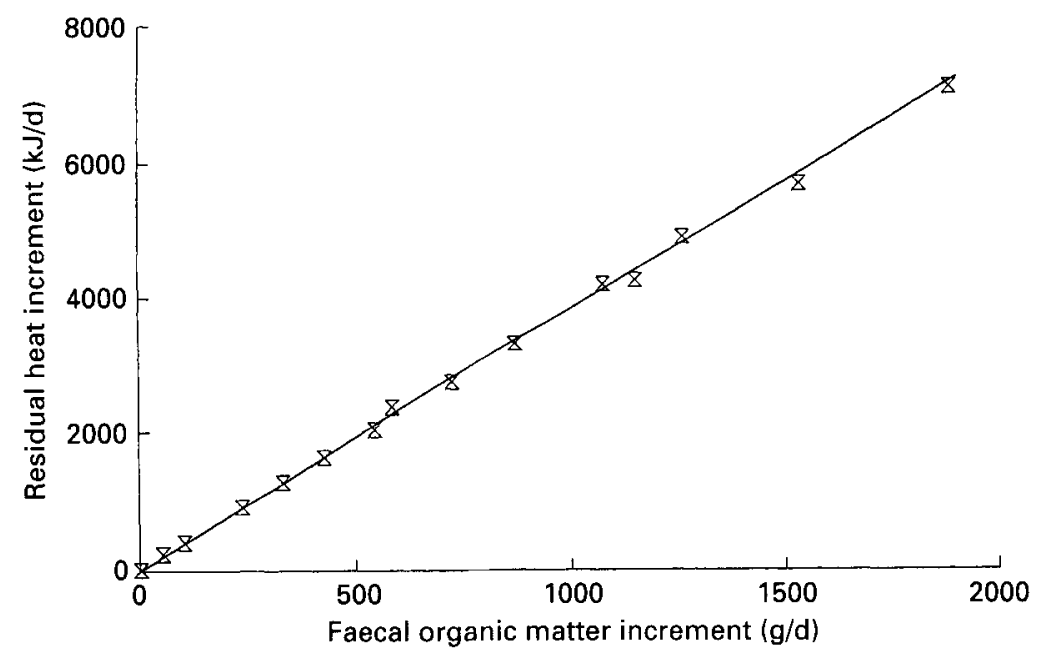

Fig. 2. The heat increment remaining after subtracting the heat increments calculated to be due to fermentation, excretion and the positive retentions of protein and lipid $(\mathrm{kJ} / \mathrm{d})$, plotted $v$. the increment in faecal organic matter (g/d) for fifteen cattle experiments. ( $\longrightarrow$ ), Represents the assumption that all the residual heat increment is associated with the production of faecal organic matter at the rate of $3.80 \mathrm{~kJ} / \mathrm{g}$. For details, see Tables 1 and 2 .

was such that the correlations between the five independent variables, given in Table 3, were small enough to allow multiple regression to be used. The derived regression equation was:

$$
\mathrm{H}(\mathrm{kJ} / \mathrm{d})=40+29 \cdot 1 \mathrm{UN}+0 \cdot 612 \mathrm{MTHE}+3.80 \mathrm{FOM}+36.2 \mathrm{PR}+16.4 \mathrm{LR} \text {. }
$$

The residual standard deviation (RSD) was only $85 \mathrm{~kJ} / \mathrm{d}$ and with $R^{2}$ above 0.999 , the regression accounted for virtually all the variation. The intercept had a standard error of 45 and was not significantly different from zero. The standard errors of the five coefficients were all less than 0.03 of the estimated values. After rounding, the values for the five coefficients $(\mathrm{kJ} / \mathrm{g})$ were taken to be: $\mathrm{w}_{\mathrm{u}} 29 \cdot 2, \mathrm{w}_{\mathrm{m}}(\mathrm{kJ} / \mathrm{kJ}) 0 \cdot 616, \mathrm{w}_{\mathrm{d}} 3 \cdot 80, \mathrm{w}_{\mathrm{p}} 36 \cdot 5$ and $\mathrm{w}_{\mathrm{l}} 16 \cdot 4$. With these values the actual HI was that predicted with a RSD of $72 \mathrm{~kJ} / \mathrm{d}$.

In the system proposed here the effect of food digestibility on energetic efficiency is, when all other effects have been properly allowed for, only through the HI of the $w_{d}$. FOM quantity. As the values for all the coefficients except $w_{d}$ could have been estimated from other published estimates (see p. 818), the heat not accounted for by all the terms except $\mathrm{w}_{\mathrm{d}}$. FOM, calculated using the previously stated values of the other coefficients, is shown plotted $v$. FOM in Fig. 2 ; the line drawn has a slope of $3.80 \mathrm{~kJ} / \mathrm{g}$. 
Table 4. The increments in certain daily quantities, and their energy equivalents $(k J)$, where pigs were given a basal diet with an increment of sugar (data from Fingerling et al. $1938 \mathrm{a})$

\begin{tabular}{lc}
\hline \multicolumn{1}{c}{ Quantity } & Energy $(\mathrm{kJ} / \mathrm{d})$ \\
\hline ME & 6315 \\
Weight correction & -341 \\
Corrected ME & 6656 \\
Energy retention & 4648 \\
Heat & 2008 \\
29.2 UN & -27 \\
$3 \cdot 8$ FOM & 13 \\
$36 \cdot 5$ PR & 123 \\
Heat of lipid retention* & 1899 \\
Lipid retention $(\mathrm{g})$ & $115 \cdot 4$ \\
W & $16 \cdot 4 \mathrm{~kJ} / \mathrm{g}$ \\
\hline \hline
\end{tabular}

UN, FOM and PR, the increments in the quantities of urinary $\mathrm{N}$, faecal organic matter and positive protein retention $(\mathrm{g} / \mathrm{d})$; ME, metabolizable energy.

* The heat increment associated with the increment of lipid retention is the total heat increment of $2008 \mathrm{~kJ} / \mathrm{d}$ minus the calculated heat increments due to the other activities of $(-27+13+123)=109$.

\section{Heat increment of fattening in pigs}

The cattle data in Table 1 gave an estimate for $w_{1}$ of $16.4 \mathrm{~kJ} / \mathrm{g}$. In single-stomached animals the heat production associated with lipid retention is expected to depend on the proportion of the lipid retained which comes directly from feed lipid (Agricultural Research Council, 1981). In this section two experiments on pigs are used to estimate the heat of lipid retention, when it does not come from feed lipid and when it apparently does.

Fingerling et al. (1938a) gave two pigs a basal diet supplemented with sugar in one period and the basal diet alone in the immediately succeeding period. The data in Table 4 were used to estimate the value of $w_{1}$ after allowing for other sources of $H I$ using $w_{u} 29 \cdot 2, w_{a} 3 \cdot 80$ and $w_{p} 36.5 \mathrm{~kJ} / \mathrm{g}$, the values which came from the analysis of the cattle experiments. The value of $w_{1}$ was estimated as $16.4 \mathrm{~kJ} / \mathrm{g}$, which agrees with the value found from the cattle experiments.

Fingerling et al. (1938b) gave pigs (six were used, but one was excluded as it had an irregular pattern of defaecation in one period) a basal diet in two periods and, in an intermediate period, the same basal diet supplemented with $180 \mathrm{~g}$ oil $/ \mathrm{d}$. The data are given in Table 5.

HI due to UN, FOM and PR were estimated using $\mathrm{w}_{\mathrm{u}} 29 \cdot 2, \mathrm{w}_{\mathrm{d}} 3.80$ and $\mathrm{w}_{\mathrm{p}} 36.5 \mathrm{~kJ} / \mathrm{g}$, as before. The sum of these increments was subtracted from the total heat production to leave a residual heat production $(\mathrm{RH})$ presumed to be due only to maintenance, $\mathrm{MH}$, and the heat production of lipid retention. Between periods $\mathrm{MH}$ was assumed to be a linear function of live weight; both the intercept and the slope were allowed to vary between pigs. The heat production of lipid retention, HP (LR) $(\mathrm{kJ} / \mathrm{d})$, was assumed to be:

$$
\operatorname{HP}(\mathrm{LR})(\mathrm{kJ} / \mathrm{d})=\mathrm{b}_{1} . \mathrm{DL}+\mathrm{b}_{2} \cdot(\mathrm{LR}-\mathrm{DL}),
$$

where DL is digested lipid $(\mathrm{g} / \mathrm{d})$ and LR is total lipid retention $(\mathrm{g} / \mathrm{d})$; in all cases $(\mathrm{LR}-\mathrm{DL})$ was positive. To estimate $\mathrm{MH}$ for each pig, and the values of the parameters $b_{1}$ and $b_{2}$, regression of $\mathrm{RH} v$. live weight $(\mathrm{W} ; \mathrm{kg}), \mathrm{DL}$ and $(\mathrm{LR}-\mathrm{DL})$ was performed. It was found that including the intercepts did not reduce the residual mean square. The regression with no intercept was:

$$
\mathrm{RH}(\mathrm{kJ} / \mathrm{d})=4.47 \mathrm{DL}+16.7(\mathrm{LR}-\mathrm{DL})+\mathrm{m} . \mathrm{W}, \quad \text { RSD } 210,
$$


Table 5. The effect of a basal diet with or without a supplement of oil on the quantities of metabolizable energy $(M E)$, urinary nitrogen $(U N)$, protein retention $(P R)$, lipid retention $(L R)$, faecal organic matter $(F O M)$, energy retention $(E R)$, heat $(H)$, digested lipid $(D L)$ and live weight in pigs* (data from Fingerling et al. 1938 b)

(Mean values for five pigs)

\begin{tabular}{|c|c|c|c|}
\hline $\begin{array}{l}\text { Period... } \\
\text { Diet... }\end{array}$ & $\begin{array}{c}1 \\
\text { Basal }\end{array}$ & $\begin{array}{c}2 \\
\text { Basal + oil }\end{array}$ & $\begin{array}{c}3 \\
\text { Basal }\end{array}$ \\
\hline $\operatorname{ME}(\mathrm{kJ} / \mathrm{d})$ & 18872 & 26142 & 19147 \\
\hline $\mathrm{UN}(\mathrm{g} / \mathrm{d})$ & 26.95 & $28 \cdot 52$ & $30 \cdot 15$ \\
\hline $\operatorname{PR}(\mathrm{g} / \mathrm{d})$ & $55 \cdot 23$ & 46.86 & 36.86 \\
\hline $\mathrm{LR}(\mathrm{g} / \mathrm{d})$ & 117.92 & $242 \cdot 18$ & $78 \cdot 86$ \\
\hline $\mathrm{FOM}(\mathrm{g} / \mathrm{d})$ & $153 \cdot 6$ & 155.9 & $156 \cdot 4$ \\
\hline $\mathrm{ER}(\mathrm{kJ} / \mathrm{d})$ & 5984 & 10706 & 3999 \\
\hline Heat $(\mathrm{kJ} / \mathrm{d})$ & 12888 & 15436 & 15148 \\
\hline PHIl $(\mathrm{kJ} / \mathrm{d}) \dagger$ & 3386 & 3136 & 2820 \\
\hline $\operatorname{RESH}(\mathrm{kJ} / \mathrm{d}) \ddagger$ & 9502 & 12300 & 12328 \\
\hline $\mathrm{DL}(\mathrm{g} / \mathrm{d})$ & $27 \cdot 56$ & $203 \cdot 74$ & $27 \cdot 62$ \\
\hline Live wt (kg) & $95 \cdot 88$ & $130 \cdot 30$ & 137.32 \\
\hline
\end{tabular}

PHI1, heat increment due to excretion, FOM production and positive retention of protein; RESH, heat increment remaining after subtracting PHI1.

* For details, see p. 809 .

$\dagger(29.2 \times \mathrm{UN})+(3.80 \times \mathrm{FOM})+(36.5 \times \mathrm{PR})$.

$\ddagger \mathrm{H}-\mathrm{PHI}$.

where $\mathrm{m}$ had different values for the five pigs. The value of the coefficient for lipid apparently formed from non-lipid of 16.7 (SE 2.0 ) kJ/g was close to, and not significantly different from, that expected of $16.4 \mathrm{~kJ} / \mathrm{g}$. The heat production of lipid retention that was not from feed lipid was fixed, therefore, at $16.4(\mathrm{LR}-\mathrm{DL}) \mathrm{kJ} / \mathrm{d}$, and regression of the variable $\mathrm{RH} 2=\mathrm{RH}-16.4(\mathrm{LR}-\mathrm{DL}) v . \mathrm{DL}$ and $\mathrm{W}$ was performed, again with a different coefficient for $\mathrm{W}$ allowed for each pig. The regression was:

$$
\mathrm{RH} 2(\mathrm{~kJ} / \mathrm{d})=4.43 \mathrm{DL}+\mathrm{m} . \mathrm{W}, \quad \text { RSD } 198 .
$$

The RSD was no greater than that for the previous regression. The value of the regression coefficient of 4.43 (SE 0.65 ) kJ/g, estimates HP (LR) where it apparently comes from feed lipid. Since the heat of combustion of lipid is $39.6 \mathrm{~kJ} / \mathrm{g}$ the energetic efficiency of lipid retention from feed lipid is estimated as $39 \cdot 6 /(39 \cdot 6+4 \cdot 4)=0.90$ which is in line with expectations (Agricultural Research Council, 1981). The mean value of $\mathrm{m}$ was 82.5 (SE $2 \cdot 5) \mathrm{kJ} / \mathrm{kg}$ per $\mathrm{d}$.

\section{Poultry}

Male broiler chickens (Hakasson et al. $1978 a, b$ ) were fed ad lib. on two feeds of different energy contents; feed $\mathrm{L}(n 15)$ yielded $10.1 \mathrm{~kJ} \mathrm{ME} / \mathrm{g}$ and $34.4 \mathrm{~g}$ FOM/MJ ME and feed $\mathrm{H}(n$ 18) $13.1 \mathrm{~kJ} \mathrm{ME} / \mathrm{g}$ and $14.5 \mathrm{~g} \mathrm{FOM} / \mathrm{MJ} \mathrm{ME}$. The birds were grown from $1 \mathrm{~d}$ old, at about $0.04 \mathrm{~kg}$, to a series of weights between 0.5 and $4.0 \mathrm{~kg}$ when they were slaughtered and their empty bodies analysed for protein and lipid. For each bird, lipid retention ( $\mathrm{g} / \mathrm{bird}$ ) was calculated from its initial live weight and its final lipid weight. The apparent protein retention $(\mathrm{g} / \mathrm{bird})$ was calculated in the same way. Actual protein retention $(\mathrm{g} / \mathrm{bird})$ included an estimate of the small amount of protein lost from the integument from data given by the authors.

The apparently digested protein (DCP;g/bird) and FOM (g/bird) were estimated for each bird from their digestibility measurements and feed intake. The protein catabolized 
Table 6. Mean values (scaled to the cumulative $\mathrm{kg}$ body protein d) of the quantities of metabolizable energy (ME), protein catabolized (PCAT), faecal organic matter (FOM), protein retained $(P R)$, lipid retained $(L R)$ and heat $(H)$ per $\mathrm{kg}$ body protein per $d$ in a serialslaughter experiment on chickens given two feeds $(L \text { and } H)^{*}$ (data from Hakansson et al. $1978 \mathrm{a}, \mathrm{b})$

\begin{tabular}{|c|c|c|c|c|c|}
\hline \multirow[t]{2}{*}{$n \ldots$} & \multicolumn{2}{|c|}{$\begin{array}{c}\text { Feed L } \\
15\end{array}$} & \multicolumn{2}{|c|}{$\begin{array}{c}\text { Feed H } \\
18\end{array}$} & \multirow{2}{*}{$\begin{array}{l}\text { Statistical } \\
\text { significance } \\
\text { of differenc }\end{array}$} \\
\hline & Mean & SD & Mean & SD & \\
\hline $\mathrm{ME}(\mathrm{kJ})$ & 7514 & 2180 & 8974 & 3204 & NS \\
\hline PCAT $(\mathrm{g})$ & 63.88 & $13 \cdot 4$ & $57 \cdot 44$ & $14 \cdot 3$ & NS \\
\hline FOM (g) & $260 \cdot 5$ & 77.8 & $128 \cdot 3$ & 44.7 & $P<0.001$ \\
\hline$P R(g)$ & $62 \cdot 86$ & $25 \cdot 2$ & 73.63 & $32 \cdot 1$ & NS \\
\hline LR (g) & 17.34 & 6.85 & 42.69 & $19 \cdot 5$ & $P<0.001$ \\
\hline Heat $(\mathrm{kJ})$ & 5331 & 1337 & 5531 & 1696 & NS \\
\hline
\end{tabular}

NS. not significant

* Feed L had significantly more scaled FOM, and significantly less scaled LR than feed H.

(PCAT) was DCP - PR (g/bird). ER ( $\mathrm{kJ} /$ bird) was calculated as $23.8 \mathrm{PR}+39.6 \mathrm{LR}$ and $\mathrm{H}$ (kJ/bird) as $\mathrm{ME}_{\mathrm{c}}-\mathrm{ER}$, where $\mathrm{ME}_{\mathrm{c}}$ is the classical ME intake $(\mathrm{kJ} /$ bird). $\mathrm{H}$ was assumed to be due to $w_{u} \cdot 0 \cdot 16 . P C A T, w_{d} \cdot$ FOM, $w_{p} \cdot$ PR, $w_{1}$. LR and MH. As the experiment was of a serial-slaughter design, $\mathrm{MH}$ had to be estimated from the data.

A unit of maintenance, $\mathrm{MU}$, was taken as a $\mathrm{kg}$ body protein $\mathrm{d}$, with feather protein excluded. From the data the number of MU for each bird in each week could be estimated, and these accumulated from start to slaughter as CMU, the cumulative number of maintenance units in $\mathrm{kg}$ body protein $\mathrm{d}$. The raw data were, in the nature of the design of the experiment, appreciably skewed. The skewness was considerably reduced by dividing all quantities by CMU. The resulting scaled means are shown in Table 6 . The mean scaled $\mathrm{H}$ values were similar for the two feeds; feed L had significantly more scaled FOM and significantly less scaled LR than feed $\mathrm{H}$.

The high correlations between some of the independent variables $(0.833$ between $P R$ and PCAT, and 0.803 between PR and LR) meant that multiple-regression analysis could give results that would need to be interpreted carefully. The steps in the analysis used are shown in Table 7. For the regression of scaled $\mathrm{H} v$. the four scaled independent variables the intercept was small, and not significantly different from zero, and the coefficients for FOM and LR both negative. HI due to PCAT, the smallest term, was then fixed at $29 \cdot 2 / 6 \cdot 25 \mathrm{~kJ} / \mathrm{g}$ and the resulting predicted $\mathrm{H}$ subtracted from the total; as this quantity contributed only 0.052 of the total heat, any errors in the assumed value of the parameter of $29.2 \mathrm{~kJ} / \mathrm{g}$ urinary $\mathrm{N}$, taken from the cattle data, would be small. The regression of residual scaled $\mathrm{H}$ (RH1) $v$. the scaled quantities of FOM, PR and LR was performed. The mean regression coefficients were respectively 3.27 (SE 1.4), 39.3 (SE 7.0) and 9.11 (SE 9.3) kJ/g as shown in Table 7 . None was significantly different from the expected values of $3 \cdot 80,36 \cdot 5$ and between 4.4 and $16.4 \mathrm{~kJ} / \mathrm{g}$ respectively, based on the analysis of the cattle and pig data; the value of the intercept, which estimates maintenance heat per $\mathrm{kg}$ body protein per $\mathrm{d}$, was 1552 (SE 136). However, all the coefficients had large standard errors because of the relatively high correlations.

The coefficient for FOM was fixed at $3.80 \mathrm{~kJ} / \mathrm{g}$ and the resulting HI subtracted from that remaining having already subtracted the term for PCAT. The regression of this second residual scaled $\mathrm{H}(\mathrm{RH} 2) v$. the scaled quantities of $\mathrm{PR}$ and $\mathrm{LR}$ was performed. The regression had a slightly lower RSD of $250 \mathrm{~kJ}$; the mean values of the coefficients were 36.8 
Table 7. The analysis of the heat production ( $k J / k g$ body protein per d) of chickens using values obtained in a serial-slaughter experiment on chickens given two feeds (data from Hakansson et al. $1978 \mathrm{a}, \mathrm{b})$

\begin{tabular}{|c|c|c|c|c|c|c|c|}
\hline & \multirow{2}{*}{$\begin{array}{c}\text { Feed } \\
\text { L }\end{array}$} & \multirow{2}{*}{$\begin{array}{c}\text { Feed } \\
\text { H }\end{array}$} & \multirow{2}{*}{$\begin{array}{c}\text { Intercept } \\
\quad a\end{array}$} & \multicolumn{4}{|c|}{ Regression coefficient $(b)$ for: } \\
\hline & & & & FOM & $\mathrm{PR}$ & LR & $\operatorname{RSD}(\mathrm{kJ})$ \\
\hline $\mathrm{H}$ & 5331 & 5531 & - & - & - & - & - \\
\hline HIPCAT & 298 & 268 & - & - & - & - & - \\
\hline RH1 & 5033 & 5263 & 1552 & $3 \cdot 27$ & $39 \cdot 4$ & $9 \cdot 11$ & 253 \\
\hline HIFOM & 990 & 488 & - & - & - & - & - \\
\hline RH2 & 4043 & 4775 & 1525 & - & 36.8 & $12 \cdot 4$ & 250 \\
\hline HIPR & 2294 & 2687 & - & - & - & - & - \\
\hline RH3 & 1749 & 2088 & 1535 & - & - & $12 \cdot 8$ & 246 \\
\hline HILR & 226 & 555 & - & - & -- & - & - \\
\hline RH4 & 3817 & 4220 & 1527 & - & $36 \cdot 6$ & - & 246 \\
\hline
\end{tabular}

RSD, residual standard deviation.

PCAT, FOM, PR and LR are the scaled quantities of protein catabolized, faecal organic matter, protein retention and lipid retention $(\mathrm{g} / \mathrm{kg}$ body protein $\mathrm{d})$; HIPCAT (29.2 PCAT/6.25), HIFOM (3.80 FOM), HIPR ( $36.5 \mathrm{PR})$ and HILR $(12.8 \mathrm{LR})$ are the scaled heat increments due to the respective quantities $(\mathrm{kJ} / \mathrm{kg}$ body protein d); $\mathrm{H}$ is the scaled heat (kJ); RH1 is H-HIPCAT, RH2 is RH1-HIFOM, RH3 is RH2-HIPR and RH4 is RH2HILR ( $\mathrm{kJ} / \mathrm{kg}$ body protein $\mathrm{d}$ ).

(SE 2.5) for PR and 12.4 (SE 3.8) for LR, and 1525 (SE 115) for the intercept. The values were still in line with expectations, but now had much smaller standard errors. The coefficient for scaled PR was fixed at 36.5 , the heat associated with this term subtracted from that remaining, and the regression of the new residual $\mathrm{H}(\mathrm{RH} 3) v$. the scaled quantity of LR was performed. The RSD of the regression was no higher than before, at $246 \mathrm{~kJ}$. The value of the coefficient for LR of $12 \cdot 8$ (SE 2.2) was in line with expectation in that it was between $4 \cdot 4$ and 16.4 ; it is the value expected if 0.30 of the lipid was formed from feed lipid since $(0.3 \times 4 \cdot 4)+(0.7 \times 16 \cdot 4)=12 \cdot 8$. The value of the intercept was $1535(\mathrm{SE} 81) \mathrm{kJ} / \mathrm{kg}$ body protein per $\mathrm{d}$.

Given the estimates of $w_{u} 29 \cdot 2, w_{d} 3 \cdot 80, w_{p} 36 \cdot 5$ and $w_{1} 12 \cdot 8 \mathrm{~kJ} / \mathrm{g}$, the major contributions to $\mathrm{H}$ were protein retention $(0.46$ of the total $)$ and maintenance $(0.28$ of the total). The contributions to the scaled H of 3.80 FOM, 29.2/6.25 PCAT and 12.8 LR were subtracted from the total and regression of the remainder, $\mathrm{RH} 4 v$. PR was performed, as shown in Fig. 3. To emphasize the consistency between the species the residual HI for the cattle is shown plotted $v$. the increment in positive PR in Fig. 3 using the data from Table 1. The regression coefficient for the chickens was 36.6 (SE 1.5 ) $\mathrm{kJ} / \mathrm{g}$, a value indistinguishable from that for the cattle of $36.5 \mathrm{~kJ} / \mathrm{g}$. The intercept was 1527 (SE 111) kJ/kg body protein per d. At maturity a male broiler chicken would be expected to have W of about $6.5 \mathrm{~kg}$, of which about 0.19 would be body protein, giving a mature body protein weight of about $1.25 \mathrm{~kg}$. Thus, its mature $\mathrm{MH}$ is estimated as $1527 \times 1.25=1910 \mathrm{~kJ} / \mathrm{d}$, or $470 \mathrm{~kJ} / \mathrm{kg} \mathrm{W}^{0.75}$ per $\mathrm{d}$, a value in line with expectations.

Finally, given $\mathrm{w}_{\mathrm{u}} 29 \cdot 2, \mathrm{w}_{\mathrm{d}} 3 \cdot 8, \mathrm{w}_{\mathrm{p}} 36 \cdot 5$ and $\mathrm{w}_{\mathrm{l}} 12 \cdot 8 \mathrm{~kJ} / \mathrm{g}$, the $\mathrm{MH}$ was calculated as the ME intake minus the sum of the energy retention and the predicted $\mathrm{HI}$. The regression of values of $\mathrm{MH} v$. those of $\mathrm{CMU}$ was performed after transforming both to their natural logarithms. The value of the regression coefficient, the exponent, was 1.01 (SE 0.024), which was not significantly different from unity. Thus the data were consistent with the 


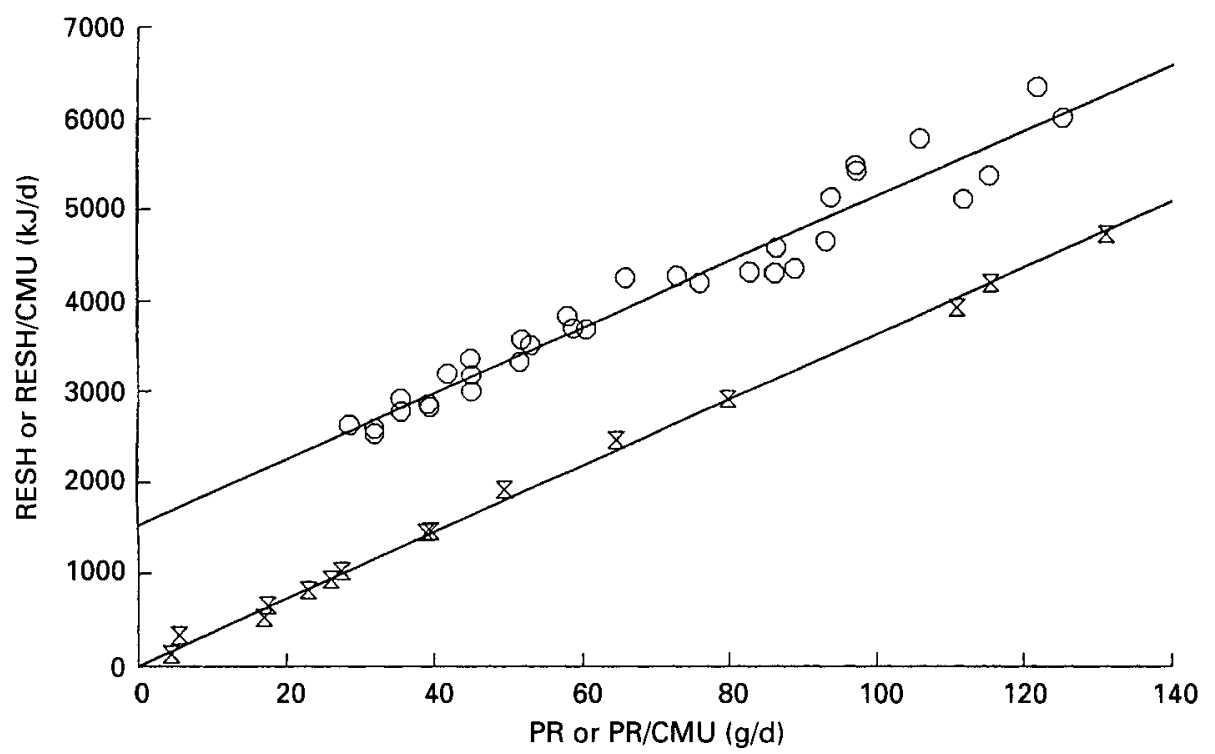

Fig. 3. The heat increment remaining after subtracting the heat increments calculated to be due to fermentation, excretion, organic matter intake and lipid retention (RESH) in chickens $(O)$ or cattle $(\Sigma)$ plotted $v$. the positive increment in protein retention (PR). For the chickens the values are both scaled by the number of cumulative maintenance units (CMU), For details, see p. 811.

maintenance scaling rule used as well as with the values of the variables which were estimated from the previous analyses of the cattle and pig experiments.

THE EFFECTIVE ENERGY SCALE AND REQUIREMENT

From the definitions given earlier (p. 803):

$$
\mathrm{ME}_{\mathrm{n}}(\mathrm{kJ} / \mathrm{d})=\mathrm{ER}_{\mathrm{n}}+\mathrm{MH}+\mathrm{HIF},
$$

where $M E_{n}$ is the $M E$, and $\mathrm{ER}_{\mathrm{n}}$ the $\mathrm{ER}$, both corrected to zero $\mathrm{N}$ retention, $\mathrm{MH}$ and $\mathrm{HIF}$ are as defined previously (p. 805). The total HIF can be seen as having two components, HIF1 and HIF2 which are given by:

$$
\begin{gathered}
\text { HIF1 }(k J / d)=w_{u} \cdot U N+w_{m} \cdot M T H E+w_{d} \cdot \text { FOM, } \\
\text { HIF2 }(k J / d)=w_{p} \cdot P R+w_{1} \cdot L R .
\end{gathered}
$$

But $\mathrm{UN}=0 \cdot 16(\mathrm{DCP}-\mathrm{PR})$, so that substituting for $\mathrm{UN}$ in equation 19 leads to:

$$
\operatorname{HIF} 1(\mathrm{~kJ} / \mathrm{d})=\mathrm{w}_{\mathrm{u}} \cdot 0 \cdot 16(\mathrm{DCP}-\mathrm{PR})+\mathrm{w}_{\mathrm{m}} \cdot \mathrm{MTHE}+\mathrm{w}_{\mathrm{d}} \cdot \text { FOM. }
$$

Since, at maintenance, $P R=0$ by definition, the value of HIF1 at maintenance becomes:

$$
\operatorname{HIFl}(\mathrm{kJ} / \mathrm{d})=\mathrm{w}_{\mathrm{u}} \cdot 0 \cdot 16 . \mathrm{DCP}+\mathrm{w}_{\mathrm{m}} \cdot \mathrm{MTHE}+\mathrm{w}_{\mathrm{d}} \cdot \text { FOM. }
$$

Subtracting HIFl from $\mathrm{ME}_{\mathrm{n}}$, the ME value measured at maintenance, gives the definition of an energy supply scale called effective energy $(\mathrm{EE} ; \mathrm{kJ} / \mathrm{d})$ :

$$
\mathrm{EE}(\mathrm{kJ} / \mathrm{d})=\mathrm{ME}_{\mathrm{n}}-0 \cdot 16 \cdot \mathrm{w}_{\mathrm{u}} \cdot \mathrm{DCP}-\mathrm{w}_{\mathrm{m}} \cdot \mathrm{MTHE}-\mathrm{w}_{\mathrm{d}} \text {. FOM. }
$$

The requirement of the animal for effective energy (EERQ; $\mathrm{kJ} / \mathrm{d}$ ) is the sum of $\mathrm{MH}$ and $\mathrm{ER}_{\mathrm{n}}$ and the $\mathrm{HI}$ of the positive lipid and protein retentions, minus the $0 \cdot 16 . \mathrm{w}_{\mathrm{u}}$. PR term to avoid double counting. The equation is:

$$
\operatorname{EERQ}(k J / d)=M H+\operatorname{PR}\left(\left(h_{p}-a\right)+\left(w_{p}-0 \cdot 16 . w_{u}\right)\right)+L R\left(h_{1}+w_{1}\right) .
$$


With $h_{1} 39 \cdot 6, h_{p} 23 \cdot 8$, a $5.63, w_{1} 16 \cdot 4, w_{p} 36.5$ and $w_{u} 29 \cdot 2 \mathrm{~kJ} / \mathrm{g}$, the requirement for effective energy becomes:

$$
\operatorname{EERQ}(\mathrm{kJ} / \mathrm{d})=\mathrm{MH}+50 \mathrm{PR}+56 \mathrm{LR} \text {. }
$$

The problem of estimating EE supplied by a diet from other information is described in the next section.

\section{ESTIMATION OF THE EFFECTIVE ENERGY \\ Ruminants}

The EE value of an ingredient for ruminants is given by:

$$
\mathrm{EE}(\mathrm{MJ} / \mathrm{kg})=\left(\mathrm{ME}_{\mathrm{n}}-\mathrm{w}_{\mathrm{m}} \cdot \mathrm{MTHE}-\mathrm{w}_{\mathrm{d}} \cdot \mathrm{FOM}\right)-0 \cdot 16 \cdot \mathrm{w}_{\mathrm{u}} \cdot \text { DCP, }
$$

where MTHE is expressed as MJ/ $\mathrm{kg}$ and FOM and DCP as $\mathrm{kg} / \mathrm{kg}$. As the DCP values for ingredients are in existing feed tables the problem is to estimate the quantity in parentheses, which is called the available energy (AVE; $\mathrm{MJ} / \mathrm{kg}$ ).

From the definitions of ME and AVE it was expected that AVE might well be able to be estimated quite accurately for different feed ingredients from their ME contents, measured at maintenance, or their GE contents $(\mathrm{MJ} / \mathrm{kg})$ and energy digestibilities $(d$; $\mathrm{MJ} / \mathrm{MJ}$ ) also measured at maintenance. The data in Fig. 4 show the AVE contents of ingredients plotted $v$. their ME contents, with both expressed on an organic matter basis; Fig. 4(a) is for forages and Fig. 4(b) for concentrates. A similar graph for wheat byproducts was obtained but is not presented for reasons of space. All the data are taken from the first, second and fourth reports of the Feedingstuffs Evaluation Unit (1975, 1978 and 1984), where feeding was at about the maintenance level. In Fig. $4(a$ and $b)$ the line drawn has the equation:

$$
\operatorname{AVE}(\mathrm{MJ} / \mathrm{kg} \text { organic matter })=1 \cdot 15 \mathrm{ME}-3.84 \text {. }
$$

For all three classes of ingredients the relationship between the available and the metabolizable energy contents was the same.

ME values in feed tables are often not measured, but estimated from digestible energy (DE) values. It is also possible to estimate the AVE value of a diet from its GE value and its $d$ value measured at maintenance. To do this the energy content of FOM was assumed to be constant at $22.5 \mathrm{~kJ} / \mathrm{g}$, a value derived as described previously. The ( $3.80 \mathrm{FOM})$ term then becomes $(0.17 \mathrm{FE})$, where $\mathrm{FE}$ is the faecal energy. The equation describing the relationship between AVE, GE and $d$ across diets was found to be:

$$
\operatorname{AVE}(\mathrm{MJ} / \mathrm{kg} \text { dry matter })=\mathrm{GE}(\mathrm{d}-0 \cdot 228) \text {, }
$$

where $\mathrm{GE}$ is expressed as $\mathrm{MJ} / \mathrm{kg}$ dry matter and $\mathrm{d}$ is expressed as $\mathrm{MJ} / \mathrm{MJ}$, measured at maintenance. Some representative data are in Fig. 5. They come from: Armsby \& Fries (1915) for the hays and mixed diets; Armstrong (1964) for dried grasses, and Feedingstuffs Evaluation Unit (1984) for straws and silages. Given the AVE estimated by either of these equations, and $\mathrm{w}_{\mathrm{u}}$ is $29.2 \mathrm{MJ} / \mathrm{kg}$, the $\mathrm{EE}$ value is:

$$
\mathrm{EE}(\mathrm{MJ} / \mathrm{kg})=\mathrm{AVE}-(0 \cdot 16)(29 \cdot 2) . \mathrm{DCP} \text {, }
$$

where DCP is expressed as $\mathrm{kg} / \mathrm{kg}$ measured at maintenance, so that the two equations become:

$$
\begin{gathered}
\mathrm{EE}(\mathrm{MJ} / \mathrm{kg} \text { organic matter })=1 \cdot 15 \mathrm{ME}-3.84-4.67 \mathrm{DCP} \\
\mathrm{EE}(\mathrm{MJ} / \mathrm{kg} \text { dry matter })=\mathrm{GE}(\mathrm{d}-0.228)-4.67 \mathrm{DCP} .
\end{gathered}
$$

\section{Single-stomached animals}

For most normal cases the MTHE value can be considered to be zero for single-stomached animals, so that EE values can be estimated from $\mathrm{ME}_{\mathrm{n}}$ and $\mathrm{DCP}$ values and the digestibility of the organic matter. 

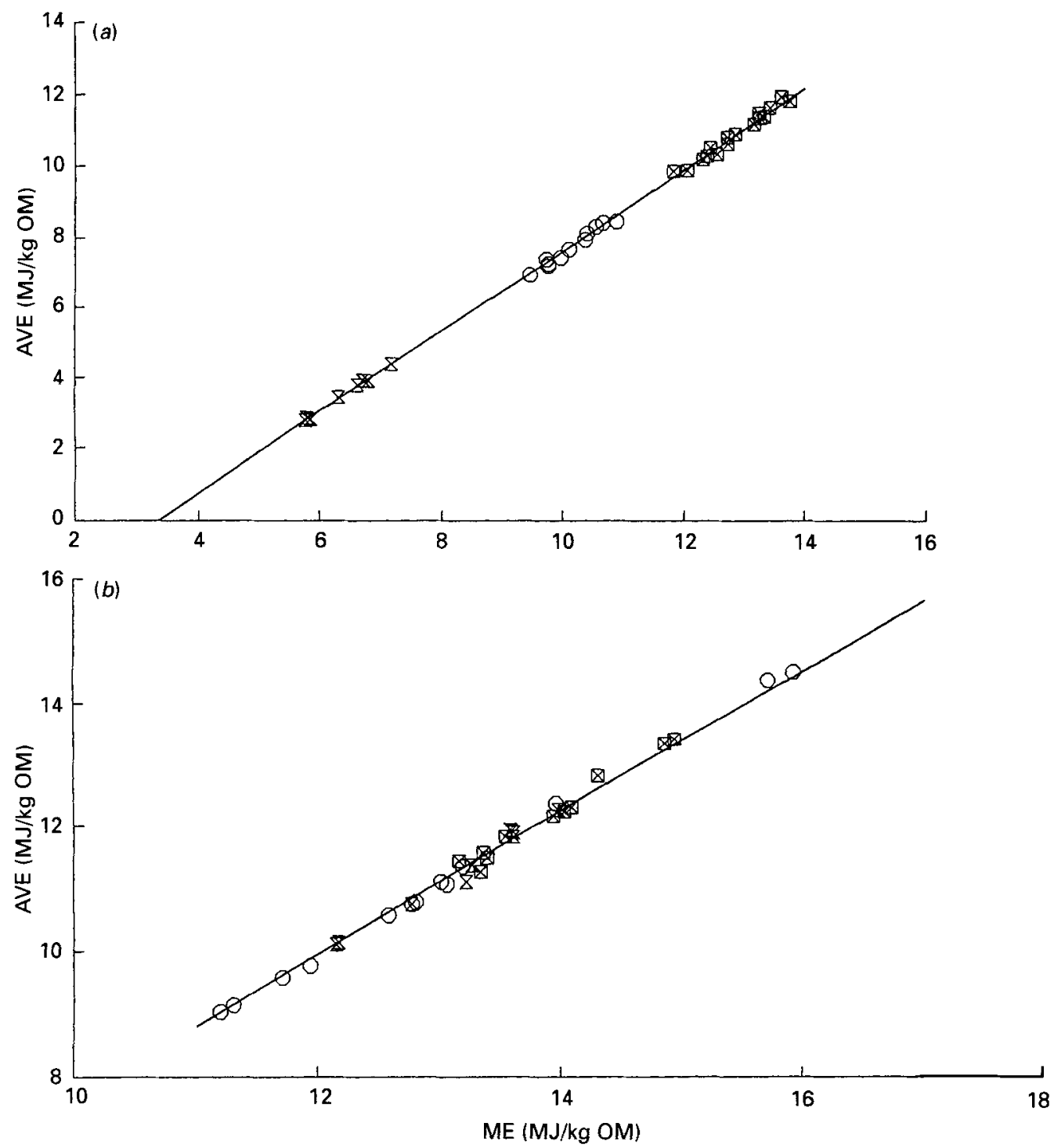

Fig. 4. The relationship between the available energy (AVE; MJ $/ \mathrm{kg}$ organic matter (OM)) and the metabolizable energy (ME; MJ $/ \mathrm{kg}$ OM) contents of $(a)$ forages ( $Z$. straws; $O$, hays; $\nabla$, silages) and $(b)$ concentrates $(Z$, cereals, cassava, sugar beet; $O$, brewers/distillers concentrate; $\otimes$, proteins). (-) AVE $=1 \cdot 15$ (ME) $-3 \cdot 84$. For details, see p. 814 .

It is convenient to treat $\mathrm{HI}$ of lipid retention as if it were a constant, $\mathrm{w}_{1}$ equal to $16.4 \mathrm{~kJ} / \mathrm{g}$, for both single-stomached animals and ruminants so that the equation for the $\mathrm{EE}$ requirement is the same as given previously. Since HI of lipid retention is less for singlestomached animals, where the lipid is apparently formed directly from feed lipid (see p. 809), the EE value of feed lipid needs to be increased. The appropriate adjustment is the difference in the $\mathrm{HI}$ of forming lipid from lipid and non-lipid which, as found previously, is $16 \cdot 4-4 \cdot 4=12 \cdot 0 \mathrm{~kJ} / \mathrm{g}$. This difference needs to be weighted by $\mathrm{z}$, the proportion of the lipid retained which apparently comes from feed lipid. With MTHE set at zero the EE value of an ingredient for single-stomached animals becomes:

$$
\mathrm{EE}(\mathrm{kJ} / \mathrm{g})=\mathrm{ME}_{\mathrm{n}}-\mathrm{w}_{\mathrm{d}} \cdot \mathrm{FOM}-0 \cdot 16 \cdot \mathrm{w}_{\mathrm{u}} \cdot \mathrm{DCP}+12 . \mathrm{z} \cdot \mathrm{DCL},
$$




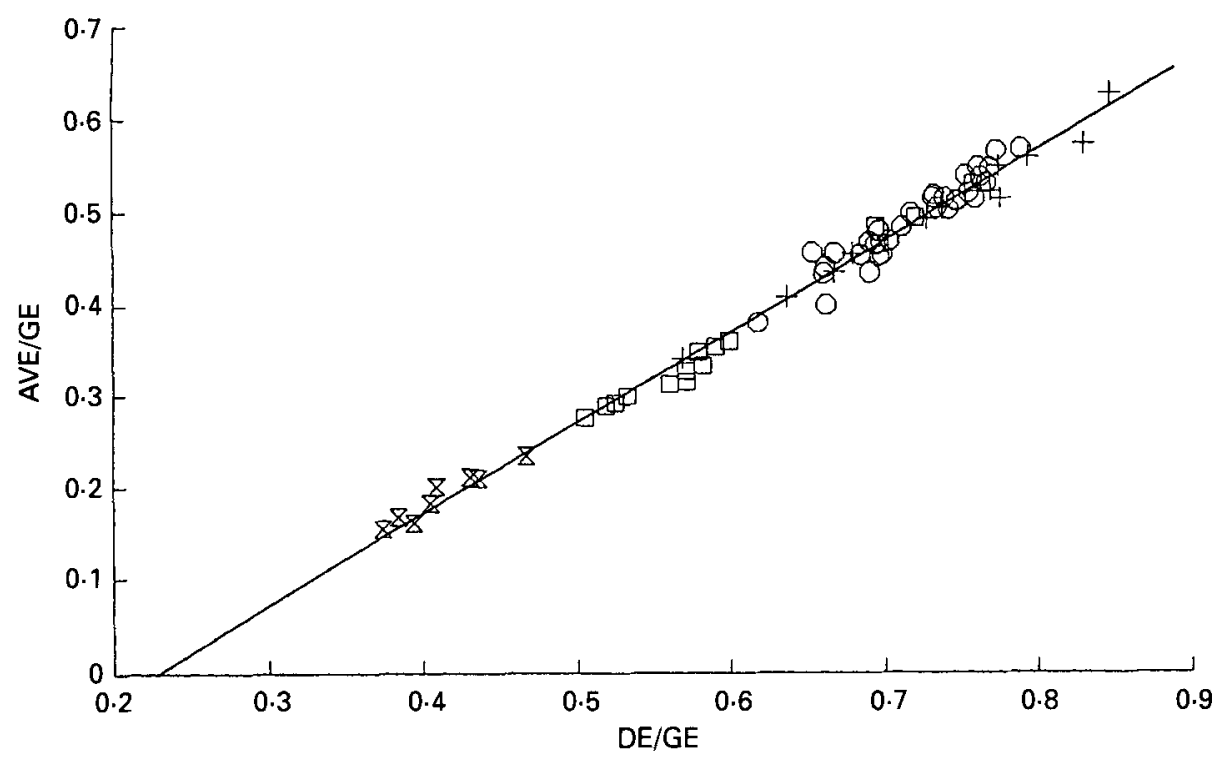

Fig. 5. The relationship between the availability (available energy (AVE)/gross energy (GE)) and the digestibility (digestible energy (DE)/GE) of the energy of different diets for ruminants: hays/mixed $(\square)$, grasses $(+)$, straws $(\mathrm{Z})$, silages $(\mathrm{O})$. For details, see p. 814 .

where DCL is digestible crude lipid $(\mathrm{g} / \mathrm{g})$ and $\mathrm{z}$ has a value between 0 and 1 . On the basis of the pig and poultry experiments analysed previously, suitable average values may be $\mathrm{z}=0 \cdot 3$ for poultry and $\mathrm{z}=1$ for pigs, but these may alter with circumstances.

The data of Hartel (1977), from forty-three diets fed to hens, were used to estimate the EE contents from other information with $12 \mathrm{z}=4$. A suitable equation was:

$$
\mathrm{EE}(\mathrm{kJ} / \mathrm{g})=1 \cdot 17 \mathrm{ME}_{\mathrm{n}}-4 \cdot 29 \mathrm{CP}-2 \cdot 44 \text {, }
$$

where $\mathrm{ME}_{n}$ is expressed as $\mathrm{kJ} / \mathrm{g}$ and $\mathrm{CP}$ is the crude protein content $(\mathrm{g} / \mathrm{g})$. The RSD was $0.08 \mathrm{~kJ} / \mathrm{g}$.

\section{DISCUSSION}

The energy systems of Armsby \& Fries (1915) and Kellner (1912,1915) both allowed energy values for ingredients to be tabulated; these were additive and could be used directly to calculate the requirements of an animal. The systems were, however, wrong in principle: Armsby \& Fries (1915) made no distinction between FHP and positive ER and Kellner $(1912,1915)$ made none between energy gained as lipid and that gained as protein. In the system described here both these errors are corrected. The EE values assigned to ingredients are additive; they are such that $1 \mathrm{~kJ}$ EE replaces $1 \mathrm{~kJ}$ lipid loss from the body. On this scale, 50 and $56 \mathrm{~kJ}$ energy are needed per $\mathrm{g}$ positive retention of protein and lipid respectively.

The system of Blaxter \& Boyne (1978) differs in principle from those of Armsby \& Fries (1915) and Kellner $(1912,1915)$ and from that described here. Their function relating ER, with no distinction made between protein and lipid, to energy intake rests on the assumption that the marginal energetic efficiency is a continuously diminishing function of energy intake. This assumption can best be tested for ruminants with the data from the experiment of Graham (1969), in which sheep attained the highest scaled intakes in any calorimeter experiment on ruminants. The data are shown in Fig. 6, together with the predictions of the system of Blaxter \& Boyne (1978). At high intakes the assumption of a 


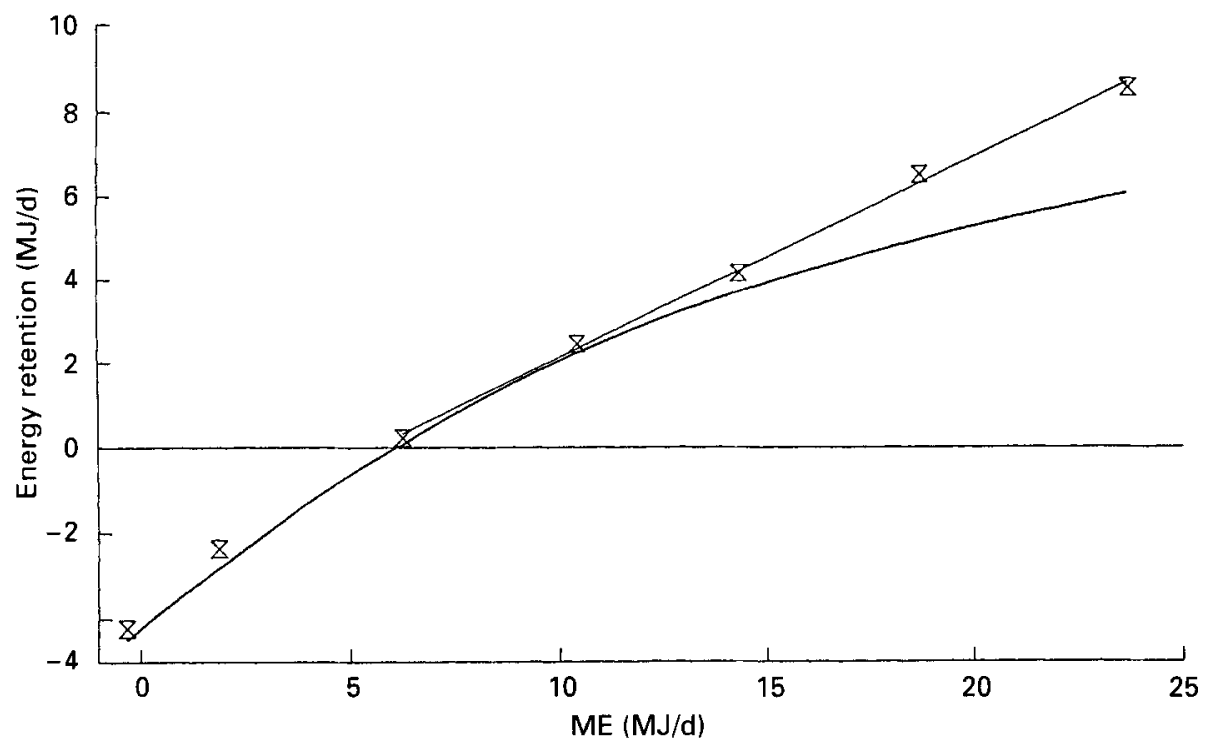

Fig. 6. The relationship between energy retention and energy supply as observed $(\varangle)$ in sheep by Graham (1969) and as predicted by two models. The curved line assumes a continuously diminishing marginal efficiency while the straight line assumes a constant marginal efficiency above maintenance.

diminishing marginal efficiency leads to large errors in prediction. Within the range of fasting to feeding at twice maintenance the errors are small, but are likely to be systematic. The assumption that the marginal energetic efficiency is a continuously diminishing function of energy intake appears to be false.

On the EE scale, as described here, energy is needed by an immature animal for only three functions: meeting $\mathrm{MH}(\mathrm{kJ} / \mathrm{d})$ which includes some level of physical activity, and $\mathrm{PR}$ $(\mathrm{g} / \mathrm{d})$ and LR $(\mathrm{g} / \mathrm{d})$. The assumption is made that the environment is thermally neutral; in a cold environment $\mathrm{ME}$ is the relevant measure of the energy supply. The important point is that the equation to express the requirement is the same for single-stomached and ruminant animals. The differences between them are dealt with by having different energy values for feed ingredients in feed tables.

It was found that the values of four of the variables, $w_{u}, w_{d}, w_{p}$ and $w_{1}$, were essentially the same for the ruminants and the single-stomached animals. The values estimated for $w_{u}$, $\mathrm{w}_{\mathrm{m}}, \mathrm{w}_{\mathrm{p}}, \mathrm{w}_{1}$ and $\mathrm{w}_{11}$ can be compared with others in the literature. Blaxter (1989) estimated the heat increment of protein given below maintenance as 0.19 of its heat of combustion, which is $4 \cdot 5 \mathrm{~kJ} / \mathrm{g}$ protein catabolized, or $4 \cdot 5 / 0 \cdot 16=28 \cdot 3 \mathrm{~kJ} / \mathrm{g}$ urinary $\mathrm{N}$. Diggs et al. (1965) proposed the same number, which is close to the estimate for $\mathrm{w}_{\mathrm{u}}$ of $29.2 \mathrm{~kJ} / \mathrm{g}$ found here. Whittemore \& Fawcett (1976) and Whittemore (1983) deducted $4.9 \mathrm{~kJ} / \mathrm{g}$ digested protein from its ME value to make protein ME equivalent to carbohydrate ME.

Webster et al. (1975) attempted to measure HI of fermentation, and found it to be about 0.6 of the energy produced as $\mathrm{CH}_{4}$, which is close to the value for $\mathrm{w}_{\mathrm{m}}$ of $0.616 \mathrm{~kJ} / \mathrm{kJ}$ found here.

In ME terms the energetic efficiency of protein retention, after due allowance for the other terms contributing to HIF, is estimated here to be $23 \cdot 8 /(23 \cdot 8+36 \cdot 5)=0.395$. This value is close to that estimated for rats on highly digestible diets by Pullar \& Webster (1977); it is towards the lower end of the values for pigs given by the Agricultural Research Council (1981), but many of these have considerable problems attached to their estimation. 
Table 8. The effects of adding $1 \mathrm{~kg}$ dry matter from three different materials to a basal diet for steers

\begin{tabular}{|c|c|c|c|}
\hline Quantity (/kg dry matter) & Straw* & Hay* & Barley $\dagger$ \\
\hline $\mathrm{ME}_{\mathrm{n}}(\mathrm{kJ})$ & 6612 & 7771 & 13524 \\
\hline $\mathrm{HIUN}=29.2 \times 0.16 \times \mathrm{DCP}(\mathrm{kJ})$ & 56 & 217 & 559 \\
\hline HIMTHE $=0.616 \times$ MTHE $(\mathrm{kJ})$ & 605 & 683 & 859 \\
\hline $\mathrm{HIFOM}=3.8 \times \mathrm{FOM}(\mathrm{kJ})$ & 1885 & 1538 & 548 \\
\hline $\operatorname{Sum}(\mathrm{kJ})$ & 2496 & 2438 & 1966 \\
\hline $\mathrm{EE}=\mathrm{ME}_{\mathrm{n}}-\mathrm{Sum}$ & 4116 & 5333 & 11558 \\
\hline $\mathrm{EE} / \mathrm{ME}_{\mathrm{n}}$ & 0.623 & 0.686 & 0.855 \\
\hline $\mathrm{MH}$ correction $=\mathrm{C}(\mathrm{kJ})$ & 30 & -84 & 285 \\
\hline PR $(\mathrm{g})$ & $31 \cdot 6$ & $50 \cdot 4$ & $27 \cdot 8$ \\
\hline $\mathrm{EE}(\mathrm{PR})=50 \times \mathrm{PR}(\mathrm{kJ})$ & 1580 & 2520 & 1390 \\
\hline $\mathrm{EE}(\mathrm{LR} ; \mathrm{kJ}) \ddagger$ & 2506 & 2897 & 10453 \\
\hline Predicted LR $(\mathrm{g}) \S$ & $44 \cdot 8$ & $51 \cdot 7$ & $176 \cdot 5$ \\
\hline Actual LR (g) & $44 \cdot 0$ & $51 \cdot 7$ & 176.2 \\
\hline$\left(\mathrm{ER}_{\mathrm{n}}+\mathrm{C}\right) / \mathrm{ME}$ & 0.355 & $0 \cdot 370$ & 0.574 \\
\hline
\end{tabular}

$\mathrm{ME}_{\mathrm{n}}$, N-corrected metabolizable energy; DCP, digestible crude protein; $\mathrm{MTHE}, \mathrm{CH}_{4}$ energy; FOM, faecal organic matter; Sum, HIUN + HIMTHE + HIFOM; EE, effective energy; MH, maintenance heat production; $\mathrm{PR}$, protein retained; $\mathrm{LR}$, lipid retained; $\mathrm{ME}$, metabolizable energy; $\mathrm{ER}_{\mathrm{n}}, \mathrm{N}$-corrected energy retention.

* Data from Kellner \& Kohler (1900); means of steers F and G.

$\dagger$ Data from Fingerling $(1933 b)$; steer $U$.

$\ddagger \mathrm{EE}-\mathrm{EE}(\mathrm{PR})-\mathrm{C}(\mathrm{kJ})$.

$\S \mathrm{EE}(\mathrm{LR}) / 56$.

The ME needed for lipid retention is estimated by the Agricultural Research Council (1981) to be $53.5 \mathrm{~kJ} / \mathrm{g}$ for pigs on cereal-based diets, which is equivalent to an energetic efficiency of 0.74 . The efficiencies estimated here are 0.900 , where lipid is apparently formed from lipid, and 0.707 when it is not; the Agricultural Research Council (1981) value is consistent with these if 0.17 of the lipid retained comes from feed lipid on cereal-based diets, which would seem to be a reasonable estimate. Czerkawski et al. (1966) found that 0.80 of the ME of additions of oil was retained by sheep. This is higher than the value found here of 0.707 , on the assumption that the HI of lipid retention in ruminants is the same from lipid as from non-lipid. However, in the experiments of Czerkawski et al. (1966), the additions of oil decreased $\mathrm{CH}_{4}$ production. When this effect is allowed for, by adding 0.616 of the reduction in $\mathrm{CH}_{4}$ energy as an estimate of $\mathrm{HI}$ of fermentation, the efficiency of retention due to the oil additions becomes 0.73 , which is similar to that expected.

As the values for four of the five variables are seen to be reasonable on other grounds, and could have been estimated from the data of other experiments, the ideas that there is a $\mathrm{HI}$ of organic matter consumption, and that this is proportional to the values of $(1-\mathrm{D})$ across foods, given the data in Table 1, are also reasonable. The value estimated for the constant of proportionality for $\mathrm{w}_{\mathrm{d}}$ of $3.80 \mathrm{~kJ} / \mathrm{g}$ cannot be directly compared with other estimates.

As EE values for ingredients can be calculated easily from data already in feed tables by the equations given previously, the system can be readily implemented for growing animals. It can be extended to deal with pregnancy, lactation and egg production by quantifying the $\mathrm{HI}$ of the components of these functions which are tasks not attempted here. The value of $\mathrm{MH}$ for a given animal can be estimated as 0.96 FHP (Forbes et al. 1928, 1930, 1931 a; Blaxter \& Wainman, 1966; Vercoe, 1970), where FHP is estimated from existing equations. Alternatively, and probably better, $\mathrm{MH}$ can be estimated from the current and mature body protein weights of the animal as described by Emmans \& Fisher (1986). 
Table 9. The daily quantities of heat $(H)$, urinary $N(U N)$, methane $(M T H E)$, faecal organic matter (FOM), and positive retentions of protein $(P R)$ and lipid $(L R)$ produced by sheep given four levels of a feed containing 0.40 chopped barley straw, together with the predicted heat increment (PHI) (data from Wainman et al. 1970)

\begin{tabular}{rrrrccccc}
\hline \hline ME $(\mathrm{kJ})$ & ER $(\mathrm{kJ})$ & $\mathrm{H}^{*}(\mathrm{~kJ})$ & UN $(\mathrm{g})$ & MTHE $(\mathrm{kJ})$ & FOM $\dagger(\mathrm{g})$ & PR $(\mathrm{g})$ & LR $(\mathrm{g})$ & PHI* $\ddagger(\mathrm{kJ})$ \\
\hline 4619 & -2452 & 7071 & $9 \cdot 63$ & 841 & 162 & 0 & 0 & 1415 \\
9410 & 544 & 8866 & $15 \cdot 93$ & 1418 & 337 & 5.94 & $10 \cdot 17$ & 3003 \\
11514 & 1364 & 10150 & $19 \cdot 77$ & 1720 & 410 & 24.38 & $19 \cdot 79$ & 4409 \\
17803 & 4109 & 13694 & $27 \cdot 83$ & 2356 & 719 & 48.69 & 74.49 & 7995 \\
\hline
\end{tabular}

ME, metabolizable energy; ER, energy retained.

* $5752+0.997$ (SE 0.022) PHI; residual SD $109 \mathrm{~kJ} / \mathrm{d}$.

+ Faecal energy $/ 22 \cdot 5$.

$+29 \cdot 2 \mathrm{UN}+0 \cdot 616 \mathrm{MTHE}+3 \cdot 80 \mathrm{FOM}+36 \cdot 5 \mathrm{PR}+16 \cdot 4 \mathrm{LR}$.

The system has been extensively tested on data from experiments on poultry, pigs, sheep and cattle which were not used in its quantification. There is not space here to describe these but, in general, the results were consistent with predictions. Examples are in Table 8, for experiments not used in Table 1, where straw, a poor hay and barley were added to a basal diet for steers. In Table 9 are data from an experiment in which sheep were given different allowances of a feed with 0.40 of its dry matter as straw. The regression of $\mathrm{H} v$. predicted HI had a coefficient of 0.997 (SE 0.022 ) which was not significantly different from the expected value of unity. When the predicted $\mathrm{HI}$ due to the productions of $\mathrm{CH}_{4}$, FOM, urinary $\mathrm{N}$ and positive LR were subtracted from $\mathrm{H}$, and the regression of the remainder $v$. positive $\mathrm{PR}$ performed, the regression coefficient, which estimates $\mathrm{w}_{\mathrm{p}}$, was 35.7 (SE 2.8$) \mathrm{kJ} / \mathrm{g}$, a value indistinguishable from those for the cattle and chickens found previously.

In the tests there were no cases where the system did worse than any of the others tested, and it often did appreciably better. As well as being in closer agreement with the facts, it is also more general and much simpler than that of the Agricultural Research Council (1980), which is based on the system of Blaxter \& Boyne (1978). It will have greater accuracy than systems based on ME with fixed efficiencies for single-stomached animals.

Blaxter \& Boyne (1978) give their view of 'the attributes of a feeding system which are important in practice'. They are that 'it should enable calculation of the performance of an animal knowing the amount and quality of the feed consumed, the amount of feed of a given quality necessary to support a particular performance, and the amount of a feed of one particular quality which substitutes for another of different quality in a diet without affecting the performance of the animal'. An energy system alone cannot have these attributes, as protein retention depends on the protein, as well as on the energy, supply. The system described here does have, to the extent that is possible of an energy system alone, the attributes seen by Blaxter \& Boyne (1978) as being important in practice.

\section{REFERENCES}

Agricultural Research Council (1980). The Nutrient Requirements of Ruminant Livestock. Slough: Commonwealth Agricultural Bureaux.

Agricultural Research Council (1981). The Nutrient Requirements of Pigs. Slough: Commonwealth Agricultural Bureaux.

Armsby, H. P. (1903). The Principles of Animal Nutrition. New York: John Wiley and Sons.

Armsby, H. P. \& Fries, J. A. (1915). Net energy values of feeding-stuffs for cattle. Journal of Agricultural Research 3,435491 . 
Armsby, H. P. \& Fries, J. A. (1917). Influence of the degree of fatness of cattle upon their utilisation of feed Journal of Agricultural Research 11, 451-472.

Armsby, H. P. \& Fries, J. A. (1918). Net energy values of alfalfa hay and of starch. Journal of Agricultural Research 15, 269-286.

Armstrong, D. G. (1964). The evaluation of artificially dried grass as a source of energy for sheep. II. The energy value of cocksfoot, timothy and strains of ryegrass at varying stages of maturity. Journal of Agricultural Research, Cambridge 62, 399-416.

Blaxter, K. L. (1989). Energy Metabolism in Animals and Man. Cambridge: Cambridge University Press.

Blaxter, K. L. \& Boyne, A. W. (1978). The estimation of the nutritive value of feeds as energy sources for ruminants and the derivation of feeding systems. Journal of Agricultural Science, Cambridge 90, 47-68.

Blaxter, K. L., Clapperton, J. L. \& Wainman, F. W. (1966), Utilisation of the energy and protein of the same diet by cattle of different ages. Journal of Agricultural Science, Cambridge 67, 67-75.

Blaxter, K. L. \& Graham, N. McC. (1955). Plane of nutrition and starch equivalents. Journal of Agricultural Science, Cambridge 46, 292-306.

Blaxter, K. L. \& Wainman, F. W. (1961). The utilisation of food by sheep and cattle. Journal of Agricultural Science, Cambridge 57, 419-425.

Blaxter, K. L. \& Wainman, F. W. (1966). The fasting metabolism of cattle. British Journal of Nutrition 20 , $103-111$.

Czerkawski, J. W., Blaxter, K. L. \& Wainman, F. W. (1966). The metabolism of oleic, linoleic and linolenic acids by sheep with reference to their effects on methane production. British Journal of Nutrition 20, 349-362.

Diggs, B. G., Becker, D. E., Jensen, A. H. \& Norton, H. W. (1965). Energy values of various feeds for the young pig. Journal of Animal Science 24, 555-568.

Emmans, G. C. \& Fisher, C. (1986). Problems of nutritional theory. In Nutritional Requirements and Nutritional Theory, pp. 9-57 [C. Fisher and K. N. Boorman, editors]. London: Butterworths.

Feedingstuffs Evaluation Unit (1975). Feedingstuffs Evaluation Unit Report no. 1. Rowett Research Institute, Aberdeen and Department of Agriculture and Fisheries, Edinburgh.

Feedingstuffs Evaluation Unit (1978). Feedingstuffs Evaluation Unit Report no. 2. Rowett Research Institute, Aberdeen and Department of Agriculture and Fisheries, Edinburgh.

Feedingstuffs Evaluation Unit (1984). Feedingstuffs Evaluation Unit Report no. 4. Rowett Research Institute, Aberdeen and Department of Agriculture and Fisheries, Edinburgh.

Fingerling, G. (1933a). Der Nahrwert von Kartoffelflocken und Kartoffelschitzeln (The nutritional value of potato flakes and chips). Landwirtschaft Versuchstationen 114, 1-112.

Fingerling, G. (1933b). Der Starkewert des Gerstenschrotes (The starch equivalent of ground barley). Landwirtschaft Versuchstationen 116, 1-63.

Fingerling, G. (1936). Aufschliessen des Strohes ohne Chemikalien (Increasing straw availability without using chemicals). Landwirtschaft Versuchstationen 125, 17-300.

Fingerling, G. (1944). Der Nahrwert der Kakaoschalen (The nutritional value of cocoa husks). Zeitschrift für Tierernährung und Futtermittelkunde 8, 25-59.

Fingerling, G., Eisenkolbe, P., Heintzsch, B., Just, M. \& Knauth, G. (1938a). Untersuchungen über den Stoff- und Energie-umsatz wachsender Schweine (Investigations into the material and energy metabolism of growing pigs). Landwirtschaft Versuchstationen 129, 193-234.

Fingerling, G., Eisenkolbe, P., Heintzsch, B., Just, M. \& Knauth, G. (1938b). Untersuchungen über den Stoff- und Energie-umsatz wachsender Schweine (Investigations into the material and energy metabolism of growing pigs). Zeitschrift für Tierernährung und Futtermittelkunde 1, 193-234.

Forbes, E. B., Braman, W. W. \& Kriss, M. (1928). The energy metabolism of cattle in relation to the plane of nutrition. Journal of Agricultural Research 37, 253-300.

Forbes, E. B., Braman, W. W. \& Kriss, M. (1930). Further studies of the energy metabolism of cattle in relation to the plane of nutrition. Journal of Agricultural Research 40, 37-78

Forbes, E. B., Braman, W. W., Kriss, M. \& Swift, R. W. (1931 a). The fasting metabolism of cattle as a base value of heat production in the determination of the net energy of feeding stuffs. Journal of Agricultural Research 43, 1003-1014.

Forbes, E. B., Braman, W. W., Kriss, M. \& Swift, R. W. (1931 b). The metabolisable energy and net energy values of corn meal when fed exclusively and in combination with alfalfa hay. Journal of Agricultural Research $\mathbf{4 3}$ 1015-1026.

Graham, N. McC. (1969). The net energy value of artificially dried subterranean clover harvested before flowering. Australian Journal of Agricultural Research 20, 365-373.

Hakansson, J., Eriksson, S. \& Svensson, S. A. (1978a). The Influence of Feed Energy Level of Feed Consumption, Growth and Development of Different Organs of Chickens. Swedish University of Agricultural Science, Department of Animal Husbandry Report no. 57. Uppsala, Sweden: Sveriges Lautbruksuniversitel.

Hakansson, J., Eriksson, S. \& Svensson, S. A. (1978b). The Influence of Feed Energy Level on Chemical Composition of Tissues and on the Energy and Protein Utilisation of Broiler Chicks. Swedish University of Agricultural Sciences, Department of Animal Husbandry, Report no. 59.

Hartel, H. (1977). Beziehungen zwischen der N-korrigierten umsetzbaren Energie und den Nahrstoffgehalten des Futters beim Huhn (The inter-relationship between metabolisable energy corrected for $\mathrm{N}$ retention and the nutrient contents of foods in hens). Archiv für Gefiügelkunde 41, 152-181. 
Kellner, O. (1912). Die Ernährung der Landwirtschaflichen Nutztiere (The Nutrition of Farm Animals). Berlin: Paul Parey.

Kellner, O. (1915). The Scientific Feeding of Animals. London: Butterworth \& Co.

Kellner, O. \& Kohler, A. (1900). Untersuchungen über den Stoff- und energieumsatz volljahrigen Ochsen bei Erhaltungsfutter (Investigations into the material and energy exchanges in mature oxen fed production rations). Landwirtschaft Versuchstationen 47, 1-474.

Kielanowski, J. (1965). Estimates of the energy cost of protein deposition in growing animals. In Proceedings of the Symposium on Energy Metabolism. European Association of Animal Production Publication no. 11, pp. 13-20 [K. L. Blaxter, editor]. London: Academic Press.

Nehring, K., Schiemann, R. \& Hoffman, L. (1961). Die Verwertung der Futterenergie in Abhangigkeit vom Ernährungsniveau (The utilization of food energy in relation to the plane of nutrition). Archiv für Tierernährung 11, 158-204.

Pullar, J. D. \& Webster, A. J. F. (1977). The energy cost of fat and protein deposition in the rat. British Journal of Nutrition 37, 355-363.

Vercoe, J. E. (1970). The fasting metabolism of Brahman, Africander and Hereford $\times$ Shorthorn cattle. British Journal of Nutrition 24, 599-606.

Wainman, F. W., Blaxter, K. L. \& Pullar, J. D. (1970). The nutritive value for ruminants of a complete processed diet based on barley straw. Journal of Agricultural Science, Cambridge 74, 311-314.

Webster, A. J. F., Osuji, P. O., White, F. \& Ingram, J. F. (1975). The influence of food intake on portal blood flow and heat production in the digestive tract of sheep. British Journal of Nutrition 34, 125-139.

Whittemore, C. T. (1983). Development of recommended energy and protein allowances for growing pigs. Agricultural Systems 11, 159-186.

Whittemore, C. T. \& Fawcett, R. H. (1976). Theoretical aspects of a flexible model to simulate protein and lipid growth in pigs. Animal Production 22, 87-96. 